\title{
Phytoplankton composition, photosynthesis and primary production during different hydrographic conditions at the Northwest Iberian upwelling system
}

\author{
G. H. Tilstone ${ }^{1,2, *}$, F. G. Figueiras ${ }^{1}$, L. M. Lorenzo $^{1}$, B. Arbones ${ }^{1}$ \\ ${ }^{1}$ CSIC, Instituto de Investigacións Mariñas, Eduardo Cabello 6, 36208 Vigo, Spain \\ ${ }^{2}$ Plymouth Marine Laboratory, Prospect Place, Plymouth, PL1 3DH, United Kingdom
}

\begin{abstract}
The major hydrographic conditions along the NW Iberian Peninsula are upwelling and poleward current. Changes in prevailing winds create transitional hydrographic states such as downwelling, stratification and upwelling-downwelling relaxation. Four cruises were undertaken between 44.25 and $41.14^{\circ} \mathrm{N}$ during spring, summer and winter, when there was a clear demarcation of these hydrographic conditions. We studied the effects of hydrography on phytoplankton species composition, photophysiology, light limitation and primary production (PP) derived from broad-band and spectral models. PP was significantly higher during upwelling $\left(F_{3,49}=99.41, \mathrm{p}<0.001\right.$; mean $2595 \pm$ $213 \mathrm{mg} \mathrm{C} \mathrm{m}^{-2} \mathrm{~d}^{-1}$ ) compared with all other hydrographic conditions. The poleward current had the lowest PP $\left(214 \pm 22 \mathrm{mgC} \mathrm{m}^{-2} \mathrm{~d}^{-1}\right)$. PP calculated using the spectral model ( $\left.\Sigma P P_{\mathrm{PUR}}\right)$ was greater than PP from the broad-band model $\left(\sum P P_{\mathrm{PAR}}\right)$, especially when southerly winds prevailed, and during stratified conditions when the chlorophyll maximum was deeper, irradiance levels were lower and most of the phytoplankton biomass was below the light limitation depth. During northerly winds, chl a was the single most important variable influencing the calculation of PP and the difference between $\sum P P_{\mathrm{PAR}}$ and $\sum P P_{\mathrm{PUR}}$ was small, since most of the phytoplankton biomass occurred above the light limitation depth, in saturating irradiance. Variations in hydrography were intrinsically linked to changes in phytoplankton species composition, photophysiology and PP. Over the whole region $89 \%$ of the variance in maximum photosynthetic rate $P_{m}^{B}$ was explained by daily mean spectral irradiance, biomass of flagellates and cyanobacteria and $75 \%$ of the variance in PP was explained by the alongshore Ekman transport component $\left(Q_{\mathrm{y}}\right)$, cyanobacteria and diatom biomass. $Q_{\mathrm{y}}$ alone explained $52 \%$ of the variance in PP over the shelf, which was also coupled with variations in $P_{m}^{B}$ and the biomass of diatoms and flagellates. At oceanic locations there was no relation between $Q_{\mathrm{y}}$ and $\mathrm{PP}\left(\mathrm{r}^{2}=7 \%\right)$, and $\mathrm{PP}$ co-varied with $P_{m}^{B}$ and the biomass of cyanobacteria.
\end{abstract}

KEY WORDS: Phytoplankton - Primary production - Photosynthesis - Maximum quantum yield · Light limitation · Upwelling $\cdot$ NW Iberian Peninsula

\section{INTRODUCTION}

Two major hydrographic features, upwelling and poleward flow, can be characterised during a typical yearly cycle along the NW Iberian Peninsula, which forms the northernmost limit of the African upwelling system. Upwelling is provoked by northerly winds from March to October (Fraga 1981, McClain et al. 1986). From October to April southerly winds prevail, causing the poleward flow of warm, salty water that constitutes the Portugese Coastal Counter Current (PCCC) (Frouin et al. 1990). Changes in wind direction and velocity during upwelling and poleward flows can form distinctive hydrographic transition states. Relaxation of the wind velocity during upwelling results in a shoreward migration of surface water from oceanic stations; this forms a convergence zone as ocean surface water meets previously upwelled Eastern North 
Atlantic Central Water (ENACW) at the coast (Castro et al. 1994). Downwelling occurs intermittently during the upwelling season when the winds change to southerlies (Fraga 1981). Downwelling magnifies the effects of wind relaxation and causes a stronger inshore flow of surface water of oceanic origin. Prolonged periods of wind relaxation and surface heating can cause a shallowing of the thermo- and pycnoclines, which results in stratification of the water column (Alvarez-Salgado et al. 1993).

Each hydrographic scenario is associated with a suite of environmental factors that selects a particular phytoplankton composition and in turn affects its photophysiology and primary production (PP). Phytoplankton composition in an upwelling system usually shifts from diatom dominance during upwelling, when nutrient concentrations and irradiance are high, to flagellate dominance as upwelling relaxes and the water column becomes stratified and nutrient concentrations and irradiance decrease (Smith et al. 1983, Mann 1993). Variations in wind strength and position may be intrinsically linked to co-variations in phytoplankton community structure, photophysiology and PP in this region. To date, there have been few studies on photosynthesis (e.g. Kyewalyanga et al. 1998) and PP (e.g. Bode et al. 1994) along the NW Iberian margin. Bode et al. (1994) reported higher production values along the NW Iberian margin during spring and summer upwelling events and lower values during stratified and winter mixing periods.

PP has been traditionally calculated using models that incorporate broad-band photosynthetic parameters and light (Smith 1936). These models assume that all light wavelengths in the photosynthetically active radiation (PAR) part of the spectrum (400 to $700 \mathrm{~nm}$ ) are absorbed by phytoplankton with the same efficiency. Absorption of light by phytoplankton, however, is strongly wavelength dependent (Kiefer \& Soohoo 1982, Bricaud \& Stramski 1990). The use of spectral models has greatly improved the accuracy of PP estimates (e.g. Kyewalyanga et al. 1992, Morel 1991). The extent to which temporal variations in hydrography affect broad-band and spectral models of PP, particularly in relation to light limitation, is poorly understood.

Modelling of carbon fixation in specific biogeochemical provinces and improving estimates of PP from remotely sensed data requires an understanding of the variations in photophysiology in relation to changes in environmental conditions, and an assessment of the variable(s) that influence PP (Sathyendranath et al. 1995, Behrenfeld \& Falkowski 1997). In this paper we investigate the relationship between hydrography, phytoplankton composition, photophysiology and PP along the NW Iberian upwelling margin. We also compare broad-band and spectral models during different hydrographic conditions and assess the principal variables that affect the calculation of PP during the hydrographic conditions considered.

\section{MATERIALS AND METHODS}

Study area and hydrography. Four cruises were carried out along the NW Iberian Peninsula to determine phytoplankton composition, photosynthetic parameters and PP. An onshore-offshore transect was sampled along $43^{\circ} 15^{\prime} \mathrm{N}, 9^{\circ} 10^{\prime} \mathrm{W}$ to $44^{\circ} 15^{\prime} \mathrm{N}, 9^{\circ} 25^{\prime} \mathrm{W}$ from 9 to 19 May 1994 (Cruise AMBAR) with RV 'Cornide de Saavedra' (Fig. 1a) when 17 stations were sampled (Stns T and C were revisited). From 20 to 30 June 1997, 14 stations from $100 \mathrm{~m}$ depth to the open ocean between latitudes $42^{\circ} 15^{\prime}$ and $43^{\circ} \mathrm{N}$ were sampled with RV 'Belgica' (Cruise BG9714c; Fig. 1b). From 5 to 19 January 1998, 13 stations between $41^{\circ} 04^{\prime}$ and $43^{\circ} \mathrm{N}$ were sampled with RV 'Charles Darwin' (Cruise CD110b; Fig. 1c). A Lagrangian experiment was carried out from 3 to 7 August 1998 aboard RV 'Charles Darwin' (Cruise CD114a; Fig. 1d) when 10 stations (2 each day) were sampled whilst following a drifting buoy from $42^{\circ} 5^{\prime}$ to $41^{\circ} 8^{\prime} \mathrm{N}$.

Stations were initially surveyed using a conductivitytemperature-depth (CTD) sampler (SeaBird SB-25 on Cruise AMBAR, SeaBird SBE09 on Cruise BG9714c, and a Neil Brown Systems Mk IIIB on Cruises CD110b \& CD114a) fitted with SeaTech (AMBAR) and standard Chelsea Instruments (CD110b \& CD114a) fluorometers. Maximum fluorescence peaks obtained from fluorescence profiles during CTD casts were used to determine sampling depths. On Cruise BG9714c, CTD oxygen profiles were used instead of fluorescence. On Cruise AMBAR, 2 depths (surface and chl a maximum) were sampled using 101 Niskin bottles. On Cruises BG9714c and CD114a seawater samples were collected from 3 to 5 depths in the photic layer down to $0.1 \%$ surface irradiance. On Cruise CD110b samples were collected from 4 depths in the water column using Niskin bottles at only 3 stations. Due to rough weather conditions and high water column mixing on Cruise CD110b, measurements of phytoplankton absorption, chl a and photosynthetic parameters for the other 10 stations were taken from the ship's non-toxic supply. The water column was assumed to be homogeneous to the photic layer, which was shallower than the upper mixed layer (see below).

The magnitude and direction of the wind off Cape Finisterre $\left(43^{\circ} \mathrm{N}, 11^{\circ} \mathrm{W}\right.$; Lavin et al. 1991) were deduced from surface pressure charts (3 times per day) and used to calculate Ekman transport perpendicular $\left(Q_{\mathrm{x}}\right)$ and parallel $\left(Q_{\mathrm{y}}\right)$ to the coast according to Wooster et al. (1976): 

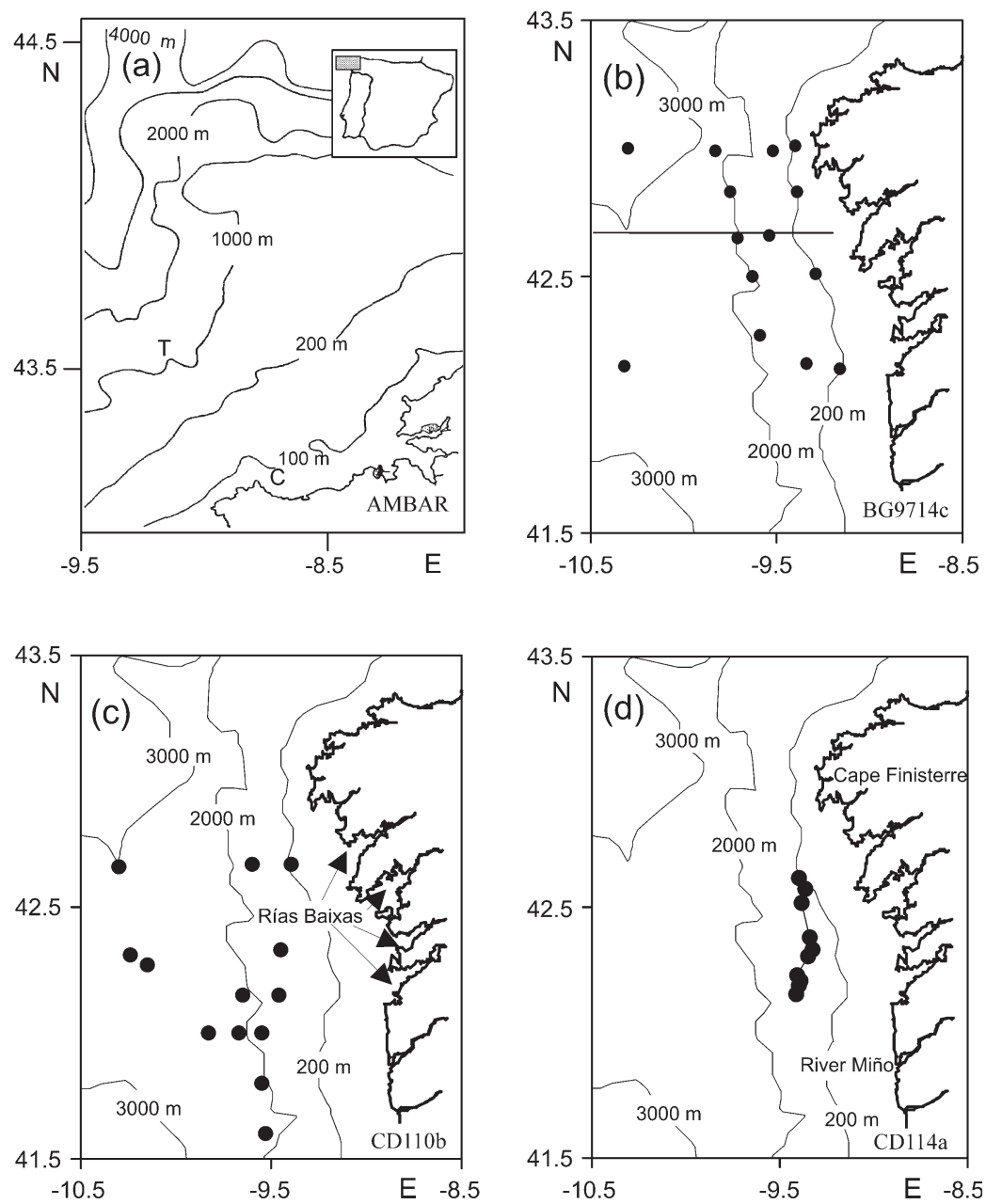

Fig. 1. Study area and sampling stations along the NW Iberian Peninsula during 4 cruises: (a) Cruise AMBAR from 9 to 19 May 1994, (b) Cruise BG9714c from 20 to 30 June 1997, (c) Cruise CD110b from 5 to 15 January 1998, (d) Cruise CD114a from 3 to 7 August 1998. Line in (b) indicates the latitudinal transect shown in Figs. $4 \mathrm{~b}$ and $6 \mathrm{~b}$. Shelf stations were classified as those at a depth $<1000 \mathrm{~m}$ and ocean stations as those at a depth $>1000 \mathrm{~m}$

$$
Q_{\mathrm{x}, \mathrm{y}}=\frac{\rho_{\mathrm{a}} C_{\mathrm{d}}|V| V_{\mathrm{y}, \mathrm{x}}}{F \times \rho_{\mathrm{w}}}
$$

where $\rho_{\mathrm{a}}$ is the air density $\left(1.22 \mathrm{~kg} \mathrm{~m}^{-3}\right), C_{\mathrm{d}}$ is the empirical drag coefficient $\left(1.3 \times 10^{-3}\right.$, dimensionless $)$ according to Hidy (1972), $|V|$ is the wind speed at the sea surface with components $V_{\mathrm{y}, \mathrm{x}}, \rho_{\mathrm{w}}$ is the density of seawater $\left(\sim 1025 \mathrm{~kg} \mathrm{~m}^{-3}\right)$ and $F$ is the Coriolis parameter at $43^{\circ} \mathrm{N}\left(9.946 \times 10^{-5} \mathrm{~s}^{-1}\right)$. The cross-shore and along-shore Ekman transport calculated at Cape Finisterre are considered representative of the general conditions for the whole of the West coast of Galicia (Blanton et al. 1984, Lavin et al. 1991). $Q_{\mathrm{x}}$ was assigned positive values to indicate upwelling. The Ekman transport values were averaged for the day of sampling plus 2 previous $\mathrm{d}$.
Aliquots were taken from Niskin bottles and frozen immediately for the analysis of nutrients in the laboratory. For Cruises AMBAR, CD110b and CD114a, nutrient concentrations were measured using a Technicon AAII SFA auto analyser. The reduction method to nitrites in a $\mathrm{Cd}-\mathrm{Cu}$ column was used to determine nitrate (Mourino \& Fraga 1985). Silicic acid and phosphates were analysed using the method of Hansen \& Grasshoff (1983) with some modifications by Alvarez-Salgado et al. (1992). For Cruise BG9714c, nitrate was also analysed on a Technicon AA II SFA auto analyser. Silicates and phosphates were measured spectrophotometrically using the methods of Grasshoff et al. (1983).

Phytoplankton identification and carbon biomass. Microplankton samples were preserved in Lugol's iodine and sedimented in composite sedimentation chambers. For chl a concentrations $\leq 2.0 \mathrm{mg} \mathrm{m}^{-3}, 100 \mathrm{ml}$ of sample was sedimented and for chl a concentrations $>2.0 \mathrm{mg} \mathrm{m}^{-3}, 50 \mathrm{ml}$ of sample was used. Diatoms, autotrophic dinoflagellates and flagellates $>20 \mu \mathrm{m}$ and autotrophic ciliates were identified and counted to the species level when possible using an inverted microscope (Utermöhl 1958). Autotrophic dinoflagellates and flagellates were identified following Lessard \& Swift (1986), and complemented by epifluorescence microscopy. Small species (20 to $30 \mu \mathrm{m}$ ) were counted in single transects at 250 and 400 and a scan of the whole slide at 100 was used for the larger species $(>30 \mu \mathrm{m})$. The dimensions of each of the species identified were measured and cell volumes were determined by approximation to the nearest geometric shape (Edler 1979). Cell carbon content was estimated following Strathmann (1967) for diatoms and dinoflagellates, Verity et al. (1992) for flagellates and Laws et al. (1984) for ciliates. In addition, on all cruises except AMBAR, $10 \mathrm{ml}$ of seawater was fixed in buffered formaldehyde $(2 \%$ final concentration) and placed in the dark for $10 \mathrm{~min}$ at $5^{\circ} \mathrm{C}$. The samples were filtered through $0.2 \mu \mathrm{m}$ black Millipore polycarbonate filters and stored at $-20^{\circ} \mathrm{C}$ in the dark until further analysis. The filters were then immersed in low fluorescence immersion oil and examined at $1000 \times$ using an epiflourescence Nikon microscope. Cyanobacteria were distinguished by yellow 
colouration and the autotrophic pico- and nanoflagellates by red colour under excitation with blue light. Cell volumes were calculated using a spherical model and converted to carbon biomass following Both (1988) for cyanobacteria and Verity et al. (1992) for pico- and nanoflagellates. For Cruise AMBAR, flagellates $<20 \mu \mathrm{m}$ were counted using the inverted microscope and therefore a clear identification of autotrophic forms within this group was not possible.

Chlorophyll and phytoplankton absorption coefficients. Chl a was determined by filtering between 100 and $250 \mathrm{ml}$ of seawater through $25 \mathrm{~mm}$ Whatman $\mathrm{GF} / \mathrm{F}$ filters and the pigment was then extracted in $90 \%$ acetone. Chlorophyll concentrations were estimated by fluorometry using a Turner Designs fluorometer (Yentsch \& Menzel 1963).

Seawater volumes of 1 to 21 were filtered through Whatman GF/F filters. The optical density spectrum (350 to $750 \mathrm{~nm}$ ) of particulate material concentrated on GF/F filters was measured in a single beam Beckman spectrophotometer (DU 650 series) at $1 \mathrm{~nm}$ bandwidth. Pre-filtered seawater was used to moisten blank GF/F filters, which were then read as blanks. The optical density of total particulate material in the sample was measured close to the photomultiplier to ensure the detection of forward scattered light. The optical density of non-algal material was determined on the same filter after pigment extraction for 30 to $60 \mathrm{~min}$ in absolute methanol following the method of Kishino et al. (1985). The difference between total particulate absorption and detrital absorption is the optical density of phytoplankton pigments on glass fibre filters. The correction for pathlength amplification on the filters and the calculation of wavelength specific phytoplankton absorption coefficient was carried out using the methods described in Arbones et al. (1996).

Light in the water column. The spectral irradiance in the water column was determined at 5 to $10 \mathrm{~m}$ intervals with a Li-1800 UW spectro-radiometer (Li-Cor) from which the attenuation coefficient $K(\lambda)$ was obtained. The incident PAR $\left(\sum_{400}^{700} \lambda\right)$ at the sea surface $\left(E_{0+}\right)$ was measured on deck at 1 min intervals with a Li-Cor cosine corrected LI-190SA sensor and then integrated hourly. $E_{0+}$ and $E_{0-}$ PAR just below the sea surface were also measured with the Li-1800 UW each time water column spectral irradiance was determined. From these measurements the average transmittance at the air-sea interface $(\tau)$ was estimated and then used to calculate the hourly average daily spectrum of the irradiance just below the sea surface, $\overline{E_{0-}}(\lambda)$. The hourly average spectral irradiance at each metre in the water column was calculated from: $\overline{E_{0-}}(\lambda)$

$$
\overline{E_{z}}(\lambda)=\overline{E_{0-}}(\lambda) \times \exp (-K(\lambda) \times Z)
$$

PAR irradiance at each depth was calculated as the sum of the irradiance between 400 and $700 \mathrm{~nm}$.

Due to adverse weather conditions from 5 to 19 January 1998 only 3 spectro-radiometer profiles were obtained during Cruise CD110b. For the rest of the stations, which were sampled at the surface only, the corresponding spectral irradiance of the water column was estimated using the Gregg \& Carder (1990) spectral solar irradiance model for cloudless skies. From 5 to 19 January 1998 conditions were cloudy; however Morel (1991) showed that cloud cover does not significantly change the daylight spectral composition. An analysis of spectral air irradiance measured during the cruise showed that the spectral form did not change significantly between cloudy days. We therefore used a mean air spectral irradiance form derived from the whole cruise and applied it to PAR values measured at each station to correct for cloud cover. Spectral air PAR $\left(E_{0+}\right)$ measurements were taken using the Li-1800UW spectro-radiometer each time surface stations were sampled, and used to calculate the spectral irradiance just below the sea surface. The average mixed layer depth of the water column was obtained from 5 CTD profiles and determined by changes in $\sigma_{t} \geq 0.05$ (Mitchell \& Holm-Hansen 1991) and in temperature $\geq 0.1^{\circ} \mathrm{C}$ (Kyewalyanga et al. 1997) over a $5 \mathrm{~m}$ depth interval. At the stations on Cruise CD110b at which the CTD was deployed, the mixed layer extended below the $0.1 \%$ irradiance level $Z$ and it was assumed that the same applied to the surface sampled stations. The spectral irradiance in the photic layer was therefore modelled using the following equation:

$$
E_{0.1 \%}(\lambda)=1 / Z_{0.1 \%} \int_{0}^{Z_{0.1 \%}} \overline{E_{0-}}(\lambda) \times \exp (-K(\lambda) \times Z) \mathrm{d} z
$$

where the attenuation coefficient $K(\lambda)$ and the air-sea transmittance $\tau$ were estimated from the mean of the 3 spectral light profiles measured during the cruise.

Photosynthesis-irradiance parameters (P-E) and integrated primary production. P-E experiments were conducted in lineal incubators illuminated at the front by $50 \mathrm{~W}, 12 \mathrm{~V}$ tungsten halogen lamps (see Arbones et al. 2000 for details of incubator design). Each incubator houses 14 sub-samples in $75 \mathrm{ml}$ Corning tissue culture flasks which were inoculated with $1.85 \times 10^{5} \mathrm{~Bq}(5 \mu \mathrm{Ci})$ of ${ }^{14} \mathrm{C}$ labelled bicarbonate. The samples were maintained at in situ sea temperature at the chl a maximum using a digital temperature controller. The photosynthetic available radiation $\left(E_{\mathrm{PAR}}\right)$ at the position of each incubation bottle was measured using a Li-Cor cosine sensor LI-190SA. The flask at the end of the incubator was covered with aluminium foil and used to measure dark ${ }^{14} \mathrm{C}$ fixation. After 2 to $3 \mathrm{~h}$ of incubation, the suspended material was filtered through $25 \mathrm{~mm}$ Whatman GF/F filters. The filters were exposed to concentrated 
$\mathrm{HCl}$ fumes for $12 \mathrm{~h}$ and then frozen. Radiocarbon activity on the filters was determined immediately on return to the Instituto de Investigacións Mariñas laboratory, in a Packard Tri-Carb 2500 TR liquid scintillation analyzer using the external standard and the channel ratio methods to correct for quenching.

The broadband P-E parameters light-saturated chl a specific rate of photosynthesis $P_{m}^{B}\left(\mathrm{mg} \mathrm{C}[\mathrm{mg} \mathrm{chl} \mathrm{a}]^{-1}\right.$ $\left.\mathrm{h}^{-1}\right)$, and the light limited slope $\alpha^{B}\left(\mathrm{mg} \mathrm{C}[\mathrm{mg} \mathrm{chl} a]^{-1}\right.$ $\mathrm{h}^{-1}\left[\mu \mathrm{mol} \mathrm{m} \mathrm{m}^{-2} \mathrm{~s}^{-1}\right]^{-1}$ ) were estimated by fitting the data to the model of Platt et al. (1980):

$$
\begin{aligned}
P_{z}^{B}= & P_{s}^{B}\left[1-\exp \left(-\alpha^{B} \times E_{\mathrm{PAR}} / P_{s}^{B}\right)\right] \times \\
& \exp \left(-\beta^{B} \times E_{\mathrm{PAR}} / P_{s}^{B}\right)
\end{aligned}
$$

where $P_{z}^{B}$ is the chlorophyll-specific rate of photosynthesis (mgC $\left.[\mathrm{mg} \mathrm{chl} \mathrm{a}]^{-1} \mathrm{~h}^{-1}\right), P_{s}^{B}$ is the light-saturated chlorophyll-specific rate of photosynthesis in the absence of photoinhibition and $\beta^{B}$ is the coefficient of photoinhibition ( $\mathrm{mgC}[\mathrm{mg} \mathrm{chl} \mathrm{a}]^{-1} \mathrm{~h}^{-1}\left[\mu \mathrm{mol} \mathrm{m} \mathrm{m}^{-2} \mathrm{~s}^{-1}\right]^{-1}$ ) at each given depth.

The spectral quality of the incident light did not change along the incubators (Figueiras et al. 1999, Arbones et al. 2000). The spectral irradiance $E_{q}(\lambda)$ at each location in the incubator was therefore deduced from the relative mean spectrum of the tungstenhalogen lamps $E_{N}(\lambda)$ multiplied by the corresponding photosynthetic available radiation $\left(E_{\mathrm{PAR}}\right)$ :

$$
E_{q}(\lambda)=E_{N}(\lambda) \times E_{\mathrm{PAR}}
$$

The photosynthetic useable radiation absorbed by

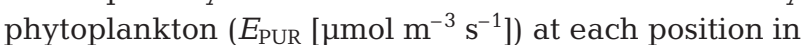
the incubator and for each sampling depth was estimated according to Dubinsky (1980):

$$
E_{\mathrm{PUR}}=\int_{400}^{700} a_{p h}(\lambda) \times E_{q}(\lambda) \mathrm{d}(\lambda)
$$

where $a_{p h}(\lambda)\left(\mathrm{m}^{-1}\right)$ is the phytoplankton absorption coefficient. $a_{p h}(\lambda)$ values from discrete CTD bottle depths were interpolated to give absorption values at each metre in the water column, and using $K(\lambda)$ values, $E_{\text {PUR }}$ was calculated for every metre and hour during daylight hours. As outlined previously, $E_{\mathrm{PAR}}$ was calculated from $K_{\mathrm{PAR}}$ values at every metre and hour over the daylight hours.

The maximum quantum yield of carbon fixation $\left.\left(\phi_{m} \text { mol C fixed [mol photons absorbed }\right]^{-1}\right)$ was determined by fitting the chl a specific photosynthetic rates $P_{z}^{B}$ $\left(\mathrm{mgC}[\mathrm{mg} \mathrm{chl} \mathrm{a}]^{-1} \mathrm{~h}^{-1}\right.$ ) to the photosynthetic useable ra-

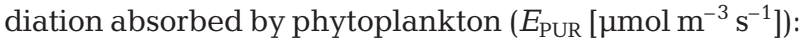

$$
\begin{aligned}
P_{z}^{B}= & P_{s}^{B}\left[1-\exp \left(-\alpha_{\mathrm{PUR}}^{B} \times E_{\mathrm{PUR}} / P_{s}^{B}\right)\right] \times \\
& \exp \left(-\beta_{\mathrm{PUR}}^{B} \times E_{\mathrm{PUR}} / P_{s}^{B}\right)
\end{aligned}
$$

where PUR denotes photosynthetic useable radiation and therefore:

$$
\phi_{m}=0.0231 \times \operatorname{chl} a \times \alpha_{\mathrm{PUR}}^{B}
$$

The factor 0.0231 converts mg C to mol, $\mu \mathrm{mol}$ of photons to mol and $h$ to sec. The light saturation parameter for light absorbed by phytoplankton $\left(\mu \mathrm{mol} \mathrm{m}^{-3} \mathrm{~s}^{-1}\right)$ is $E_{\mathrm{kPUR}}=P_{m}^{B} / \alpha_{\mathrm{PUR}}^{B}$.

The daily integrated $\mathrm{PP}\left(\sum P P, \mathrm{mg} \mathrm{C} \mathrm{m}^{-2} \mathrm{~d}^{-1}\right)$ was estimated using 2 models. The first model uses $E_{\mathrm{PAR}}$, chl a and broad-band parameters (Eq. 4) to calculate $\sum P P_{\mathrm{PAR}}$. The second model $\sum P P_{\mathrm{PUR}}$, calculated integrated PP using $E_{\mathrm{PUR}}$, chl $a$ and spectral photosynthetic parameters (Eq. 7). For both models integration was carried out at hourly steps and $1 \mathrm{~m}$ intervals from the sea surface down to $0.1 \%$ surface irradiance, which varied between 43 and $121 \mathrm{~m}$.

Light limitation in the water column. To assess the extent of light limitation in the water column the operational quantum yield $\phi$ was compared with the maximum quantum yield $\phi_{m}$ (Figueiras et al. 1999). For Cruises AMBAR, BG9714c and CD114a in situ $\phi$ was plotted against in situ $\phi_{m}$, where in situ $\phi$ was calculated by dividing in situ values of $P_{z \text { PUR }}\left(\mathrm{mol} \mathrm{C} \mathrm{m} \mathrm{m}^{-3} \mathrm{~d}^{-1}\right)$ by $E_{z \text { PUR }}$ (mol photons absorbed $\mathrm{m}^{-3} \mathrm{~d}^{-1}$ ). Under the influence of high water column mixing during the poleward current, when phytoplankton is exposed to rapidly changing light conditions, the mean $\phi$ of the photic layer was plotted against mean $\phi_{m}$. The mean operational $\phi_{0.1 \%}$ in the photic layer was then calculated as follows:

$$
\overline{\phi_{0.1 \%}}=\frac{1}{Z_{0.1 \%}} \int_{0}^{z=0.1 \%} P_{\mathrm{zPUR}} / E_{z \mathrm{PUR}} \mathrm{d} z
$$

Statistical analysis. Kolmogrov-Smirnov with Lilliefors tests were employed to check whether the distribution of each variable was normal. $\alpha, P_{m}^{B}, \phi_{m}, E_{k \text { PUR }}$ chl $a, E_{z \text { PAR }}$ and $E_{z \text { PUR }}$ were log-transformed and $E_{k \text { PAR }}$ $\sum P P_{\text {PAR }}$ and $\sum P P_{\text {PUR }}$ were square root-transformed until no significant differences were found between the expected and the observed distributions for both tests. Differences between parameters for each hydrographic regime were tested using ANOVA. Student's $t$-test was used to assess the degree of light limitation during each hydrographic phase. Stepwise multiple regression was employed to transformed data to assess the variation in photosynthetic parameters and integrated PP in relation to other biogeochemical parameters. A sensitivity analysis was performed on integrated production to assess the variable that has the greatest influence on the calculation of $\sum P P_{\mathrm{PUR}}$ during each hydrographic condition.

\section{RESULTS}

\section{Meteorological and hydrographic conditions}

Ekman transport components for the 4 cruises are given in Fig. 2 and the corresponding horizontal and 

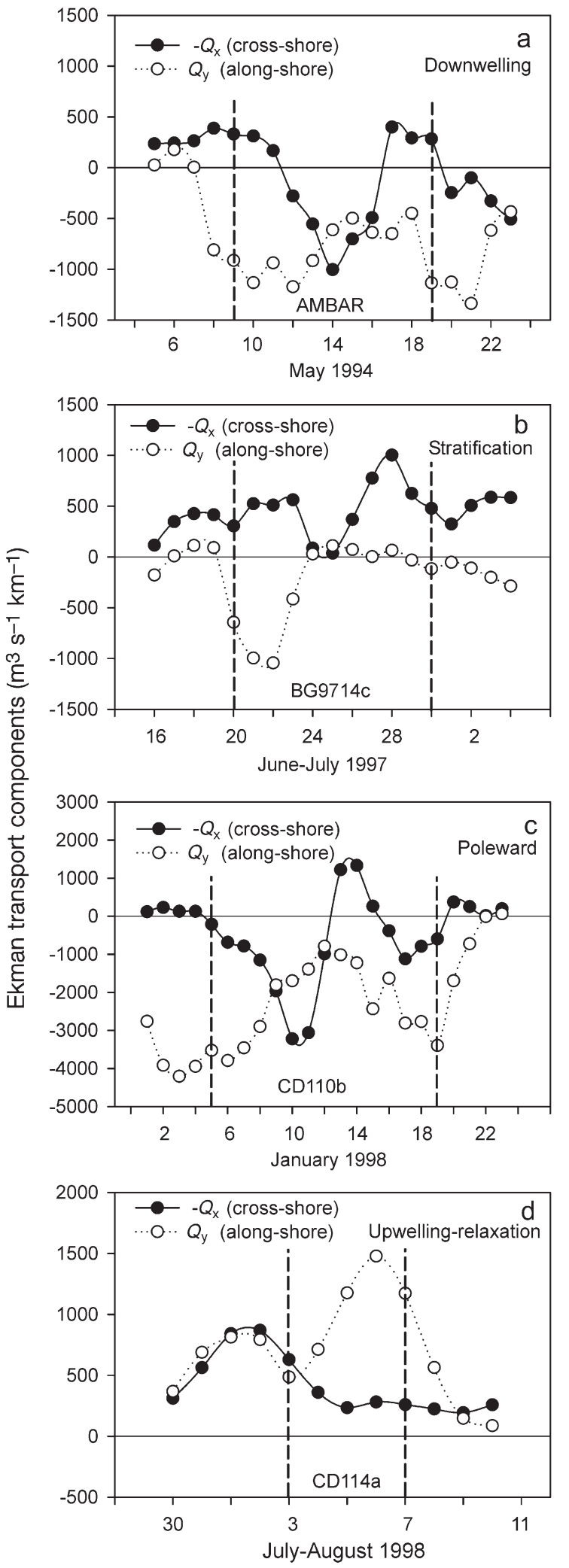

Fig. 2. Ekman transport components calculated at $43^{\circ} \mathrm{N}$, $11^{\circ} \mathrm{W}$ for the periods (a) 5 to 23 May 1994, (b) 16 June to 4 July 1997, (c) 1 to 23 January 1998, (d) 30 July to 10 August 1998. Vertical dashed lines indicate sampling periods vertical structure of the water column is given in Figs. $3 \& 4$. Cruise AMBAR, which took place in spring, occurred during a period of downwelling. On 8 May 1994 strong SW winds $\left(11.5 \mathrm{~m} \mathrm{~s}^{-1}\right)$ initiated downwelling, as indicated by negative $Q_{\mathrm{y}}$ values (Fig. 2a), which continued throughout the cruise. A composite SST image from 15 to 22 May 1994 (Fig. 3a) showed warmer, surface water south of $43^{\circ} \mathrm{N}$. Colder, surface water $\left(<13^{\circ} \mathrm{C}\right)$, indicative of a previous upwelling event, was present offshore north of $43^{\circ} \mathrm{N}$. A vertical temperature section (Fig. 4a) indicated the downwelling of surface water throughout the transect, which was stronger at the coast reaching depths of $100 \mathrm{~m}$.

From 20 to 26 June 1997 (Cruise BG9714c) a mean $Q_{\mathrm{x}}$ of $342 \mathrm{~m}^{3} \mathrm{~s}^{-1} \mathrm{~km}^{-1}$ indicated weak upwelling (Fig. 2b). From 23 to 25 June, $Q_{\mathrm{x}}$ and $Q_{\mathrm{y}}$ values were very low indicating no upwelling. $Q_{\mathrm{x}}$ was higher on 28 June, again indicating upwelling. An SST image of 24 June 1997 showed warm $\left(>19^{\circ} \mathrm{C}\right)$, surface water situated between 43 and $42^{\circ} \mathrm{N}$ (Fig. 3b) where most of the sampling occurred, and the upwelling of colder water $\left(<17^{\circ} \mathrm{C}\right)$ at the coast north of $43^{\circ} \mathrm{N}$ and south of $42^{\circ} \mathrm{N}$. The vertical temperature section (Fig. $4 \mathrm{~b}$ ) of the transect along $42.6^{\circ} \mathrm{N}$ (Fig. 1b) showed that the water column was highly stratified with high temperatures $\left(>18^{\circ} \mathrm{C}\right)$ in surface waters and lower temperatures in sub-surface waters.

From 5 to 11 January 1998 (Cruise CD110b), strong SW winds prevailed (mean wind speed $=13 \mathrm{~m} \mathrm{~s}^{-1}$ ) and the highest negative Ekman transport of all the cruises was recorded (Fig. 2c). SST images indicated that there was a warm body of water moving along the shelf in a poleward direction (Fig. 3c), which confined water with continental influence to a narrow band at the coast. Vertical profiles of temperature in the core of the poleward current during Cruise CD110b (Fig. 4c) illustrated the presence of a warm $\left(>15^{\circ} \mathrm{C}\right)$ water body in the first $100 \mathrm{~m}$, typical of a strong poleward current (Castro et al. 1997), moving northward along the slope which blocked advected colder continental water from the coast (see also Fig. 3c).

Upwelling occurred during Cruise CD114a (Fig. 2d), mainly due to NE winds. On 31 July and 1 August 1998, relatively high NE winds $\left(>9 \mathrm{~m} \mathrm{~s}^{-1}\right.$ ) initiated upwelling. From 3 to 6 August high NE winds continued (mean wind velocity $=8.3 \mathrm{~m} \mathrm{~s}^{-1}$ ) and there were high positive $Q_{\mathrm{y}}$ values. From 7 August on the upwelling relaxed. An SST image from 3 August 1998 (Fig. 3d) illustrated extensive upwelling of relatively cold water $\left(<16^{\circ} \mathrm{C}\right)$ along the coast and shelf of the NW Iberian Peninsula with the formation of 2 major cold water filaments meandering offshore at 41.5 and $42.0^{\circ} \mathrm{N}$. Two distinct hydrographic phases occurred during Cruise CD114a (Fig. 4d). On the first 2 days 

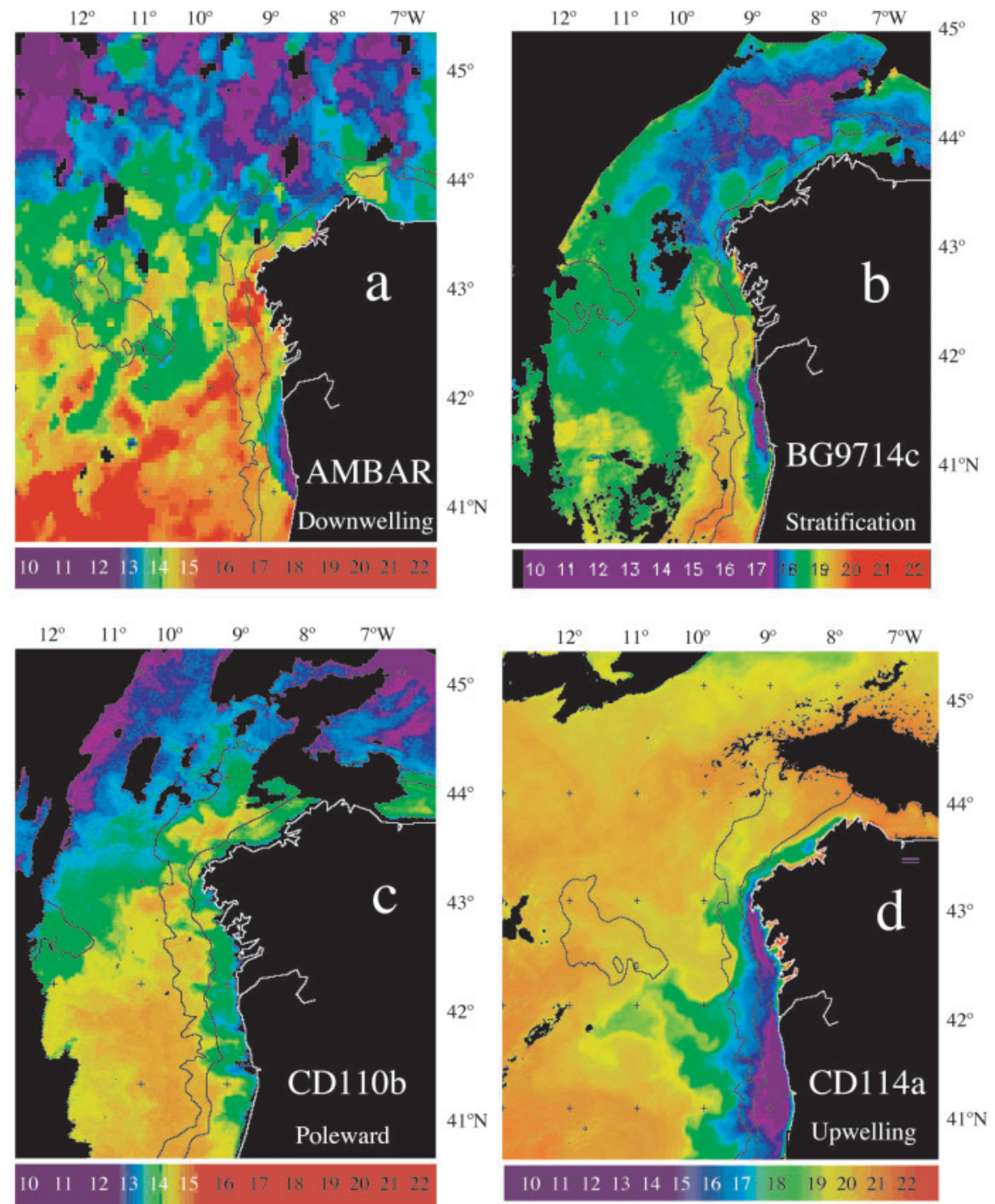

Fig. 3. AVHRR sea surface temperature images of the NW Iberian Peninsula on (a) composite image from 15 to 22 May 1994, (b) 24 June 1997, (c) 8 January 1998, (d) 3 August 1998. Note change in scale for each image

(3 \& 4 August 1998, Stns 10 to 14) there was upwelling of cold, nutrient rich ENACW, as can be seen from the shallow location of the $13^{\circ} \mathrm{C}$ isoline (mean temperature $14.3^{\circ} \mathrm{C}$ at $45 \mathrm{~m}$ ). Upwelling was followed by a relaxation event from 6 August (Stn 20), which can be traced by downward sloping temperature isolines. From 3 to 10 August 1998 during Cruise CD114a there was evidence of an upwelling-wind relaxation cycle along the shelf.

Four stations between 42.8 and $43.0^{\circ} \mathrm{N}$ during Cruise BG9714c which showed evidence of upwelling and one with strong continental influence during Cruise CD110b were omitted from any subsequent statistical analyses so that from each cruise we could characterise typical hydrographic situations: AMBAR represented spring downwelling, BG9714c represented summer stratification conditions, CD110b winter poleward flow, and CD114a summer upwelling.

Table 1 shows the nutrient concentrations over the euphotic zone during the 4 hydrographic conditions. $\mathrm{NO}_{3}$ and $\mathrm{SiO}_{4} \mathrm{H}_{4}$ values were generally $\geq 1.0 \mu \mathrm{mol} \mathrm{kg}^{-1}$ and $\mathrm{PO}_{4}$ were $\geq 0.10 \mu \mathrm{mol} \mathrm{kg}^{-1}$. Using all data and shelf data only, there were no significant differences in nutrient concentrations between hydrographic conditions. At oceanic locations significantly lower concentrations of $\mathrm{NO}_{3}\left(F_{2,36}=\right.$ 11.04, $\mathrm{p}<0.0002), \mathrm{SiO}_{4} \mathrm{H}_{4}\left(F_{2,40}=8.06\right.$, $\mathrm{p}=0.0012)$ and $\mathrm{PO}_{4}\left(F_{2,40}=3.93, \mathrm{p}=\right.$ 0.028) were found during summer stratification, but nutrients were still present, suggesting that phytoplankton was not nutrient limited.

\section{Chlorophyll and phytoplankton}

Integrated chl a values were significantly higher during spring downwelling (Cruise AMBAR; $F_{3,49}=8.38$, $\mathrm{p}<0.01$ ) (Fig. 5), when there were high sub-surface values at oceanic stations (>4 mg chl a m $\mathrm{m}^{-3}$ ) and lower values near the coast (Fig. 6a). The lowest chl a levels were found from 20 to 30 June 1997 (Cruise BG9714c) and were slightly higher at the shelf where there was a sub-surface maximum (>0.70 mg chl $a \mathrm{~m}^{-3}$ ) at $\sim 70 \mathrm{~m}$ depth (Fig. 6b). Chl a levels associated with the poleward current (Fig. 5, Cruise CD110b) were also low, but higher in coastal surface water in that period (Fig. 6c). During Cruise CD114a chl a values were relatively low for the initial upwelling conditions (Fig. 5), but increased during wind relaxation with a sub-surface maximum at $\sim 40 \mathrm{~m}$ (Fig. 6d).

Carbon biomasses of phytoplankton groups during the 4 cruises are given in Fig. 7. Total phytoplankton biomass $\left(F_{3,112}=62.95, \mathrm{p}<0.001\right)$, and the biomass of diatoms $\left(F_{3,124}=100.49, \mathrm{p}<0.001\right)$, dinoflagellates $\left(F_{3,110}=52.46, \mathrm{p}<0.001\right)$ and flagellates $\left(F_{3,112}=38.36\right.$, $\mathrm{p}<0.001)$ were highest during spring downwelling (Cruise AMBAR). Cyanobacteria were significantly higher during upwelling (Cruise CD114a) and were 

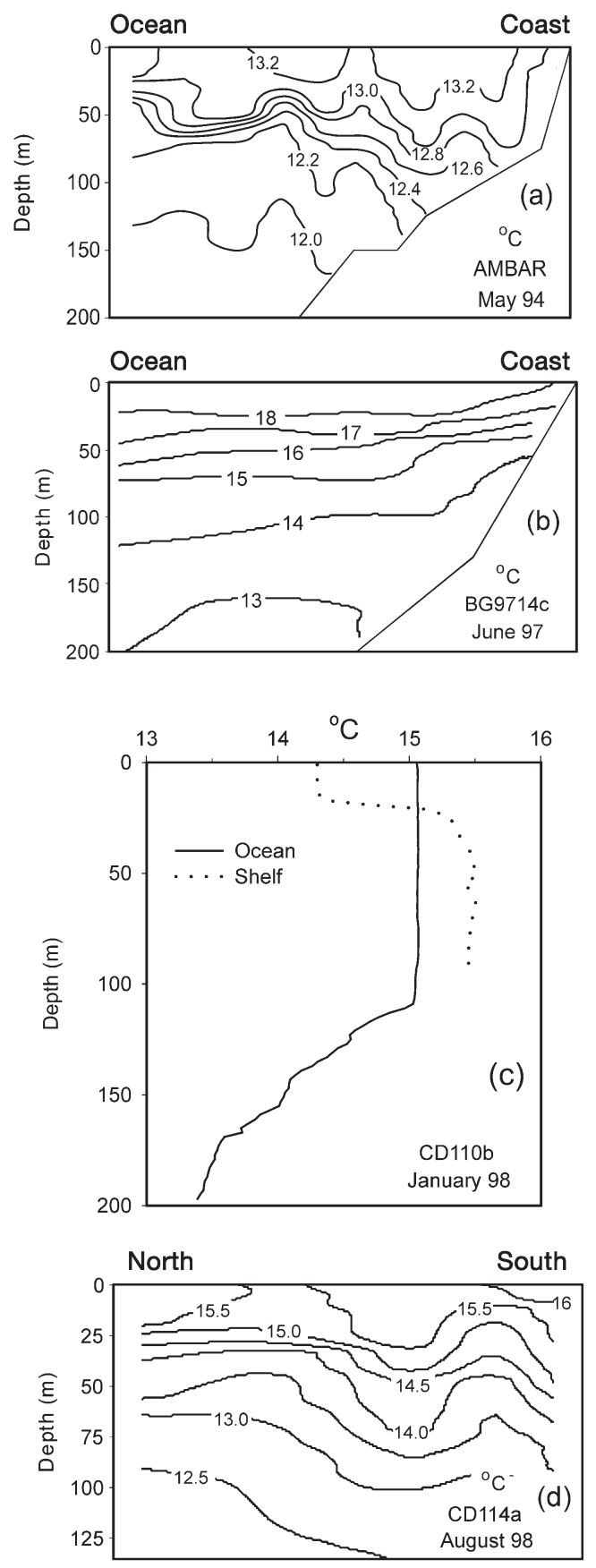

Fig. 4. Vertical distributions of temperature $\left({ }^{\circ} \mathrm{C}\right)$ for (a) May 1994 downwelling, (b) June 1997 stratification, (c) January 1998 poleward current, (d) August 1998 upwelling

generally more abundant at the shelf than offshore. Flagellates were the most abundant group overall and were generally higher in oceanic waters. Diatoms were only important in spring (Cruise AMBAR) and to a small extent during the summer upwelling relaxation (Cruise CD114a).
Table 1. $\mathrm{NO}_{3}, \mathrm{PO}_{4}$ and $\mathrm{SiOH}_{4}$ concentrations $\left(\mu \mathrm{mol} \mathrm{kg}{ }^{-1}\right.$; mean $\pm \mathrm{SE}$ ) in the euphotic zone during different hydrographic conditions and locations along the NW Iberian Peninsula

\begin{tabular}{|c|c|c|c|}
\hline & $\mathrm{NO}_{3}$ & $\mathrm{PO}_{4}$ & $\mathrm{SiOH}_{4}$ \\
\hline \multicolumn{4}{|c|}{ Spring downwelling (Cruise AMBAR, $n=34$ ) } \\
\hline Total & $1.31 \pm 0.02$ & $0.11 \pm 0.00$ & $1.30 \pm 0.03$ \\
\hline Shelf & $1.16 \pm 0.03$ & $0.10 \pm 0.00$ & $1.23 \pm 0.05$ \\
\hline Ocean & $1.47 \pm 0.04$ & $0.12 \pm 0.01$ & $1.36 \pm 0.06$ \\
\hline \multicolumn{4}{|c|}{ Summer stratification (Cruise BG9714c, $n=40$ ) } \\
\hline Total & $0.79 \pm 0.04$ & $0.10 \pm 0.00$ & $1.07 \pm 0.01$ \\
\hline Shelf & $0.99 \pm 0.07$ & $0.12 \pm 0.00$ & $1.25 \pm 0.02$ \\
\hline Ocean & $0.37 \pm 0.04$ & $0.07 \pm 0.00$ & $0.78 \pm 0.02$ \\
\hline \multicolumn{4}{|c|}{ Winter poleward flow (CD110b, $\mathrm{n}=18)$} \\
\hline Total & $0.89 \pm 0.02$ & $0.12 \pm 0.02$ & $1.69 \pm 0.18$ \\
\hline Shelf & $1.02 \pm 0.04$ & $0.15 \pm 0.01$ & $2.94 \pm 0.40$ \\
\hline Ocean & $0.73 \pm 0.06$ & $0.09 \pm 0.00$ & $0.14 \pm 0.00$ \\
\hline \multicolumn{4}{|c|}{ Summer upwelling (Cruise CD114a, $n=40$ ) } \\
\hline Total & $1.07 \pm 0.03$ & $0.11 \pm 0.00$ & $0.89 \pm 0.01$ \\
\hline Upwelling & $1.14 \pm 0.01$ & $0.12 \pm 0.00$ & $1.08 \pm 0.01$ \\
\hline Relaxation & $1.02 \pm 0.07$ & $0.10 \pm 0.00$ & $0.78 \pm 0.02$ \\
\hline
\end{tabular}

\section{Photosynthetic parameters}

The mean light limited slope, $\alpha^{B}$, maximum photosynthetic rate $P_{m}^{B}$, light saturation parameters, $E_{\mathrm{kPAR}}$ and $E_{\mathrm{kPUR}}$ and maximum quantum yield, $\phi_{m}$, for each of the 4 hydrographic conditions are given in Table 2 . $\alpha^{B}\left(F_{3,131}=30.81, \mathrm{p}<0.001\right), P_{m}^{B}\left(F_{3,131}=44.66, \mathrm{p}<\right.$ $0.001), \phi_{m}\left(F_{3,131}=11.71, \mathrm{p}<0.001\right)$ and $E_{\mathrm{kPUR}}\left(F_{3,131}=\right.$ $33.72, \mathrm{p}<0.001)$ were significantly higher during summer upwelling. $E_{\mathrm{kPAR}}\left(F_{3,131}=8.32, \mathrm{p}<0.001\right)$ was significantly higher during spring downwelling due to low $\alpha^{B}$ values. During spring downwelling, $\alpha^{B}, P_{m}^{B}$ and $\phi_{m}$ were significantly higher over the shelf $\left(F_{1,34}=\right.$ $6.72, \mathrm{p}=0.014)$ than on the ocean, but no differences were observed in $\alpha^{B}, \phi_{m}$ and $P_{m}^{B}$ between shelf and

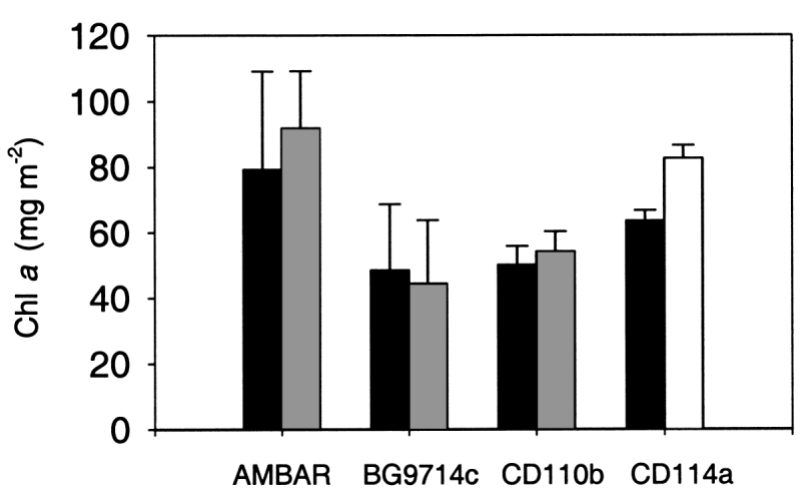

Fig. 5. Integrated chlorophyll (mean $\pm \mathrm{SD}_{;} \mathrm{mg} \mathrm{m}^{-2}$ ) during the 4 cruises along the NW Iberian Peninsula. Black bars: shelf stations; grey bars: oceanic stations. For CD114a, black bars: upwelling; white bar: upwelling-relaxation 

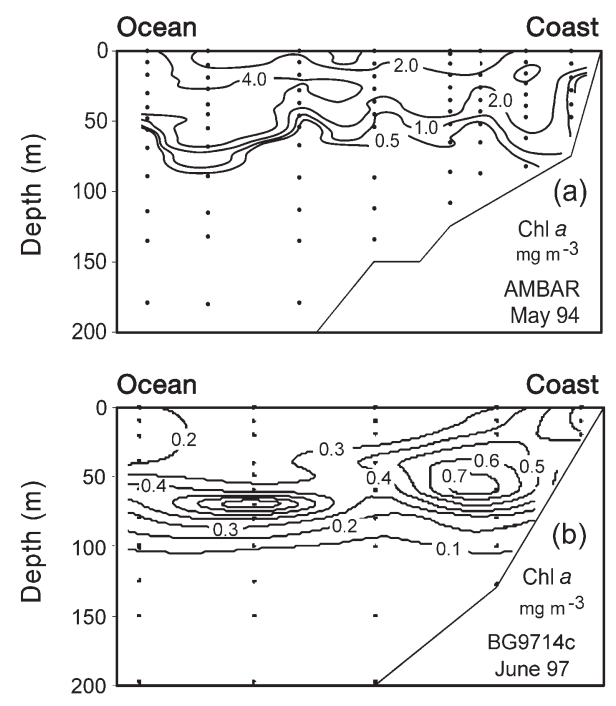

Chl a $\left(\mathrm{mg} \mathrm{m}^{-3}\right)$
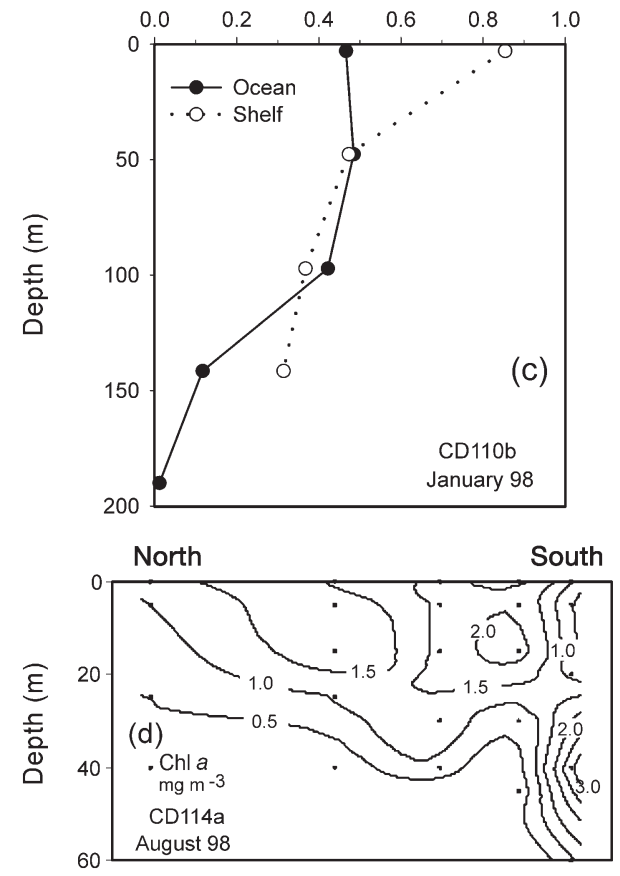

Fig. 6. Vertical distributions of $\mathrm{chl} a\left(\mathrm{mg} \mathrm{m}^{-3}\right)$ for (a) May 1994 downwelling, (b) June 1997 stratification, (c) January 1998 poleward current, (d) August 1998 upwelling

ocean regions during stratified and poleward flow conditions.

Fig. 8 plots operational $\phi$ against $\phi_{m}$ to $0.1 \%$ irradiance depth in the water column. When carbon fixation is not light limited, operational $\phi$ will be lower than the $\phi_{m}$ (Figueiras et al. 1999) since any further photons absorbed are not channelled to carbon fixation because the reaction centres are saturated. When there is light limitation in the water column, $\phi$ will be equal to $\phi_{m}$. There was evidence of light limi-
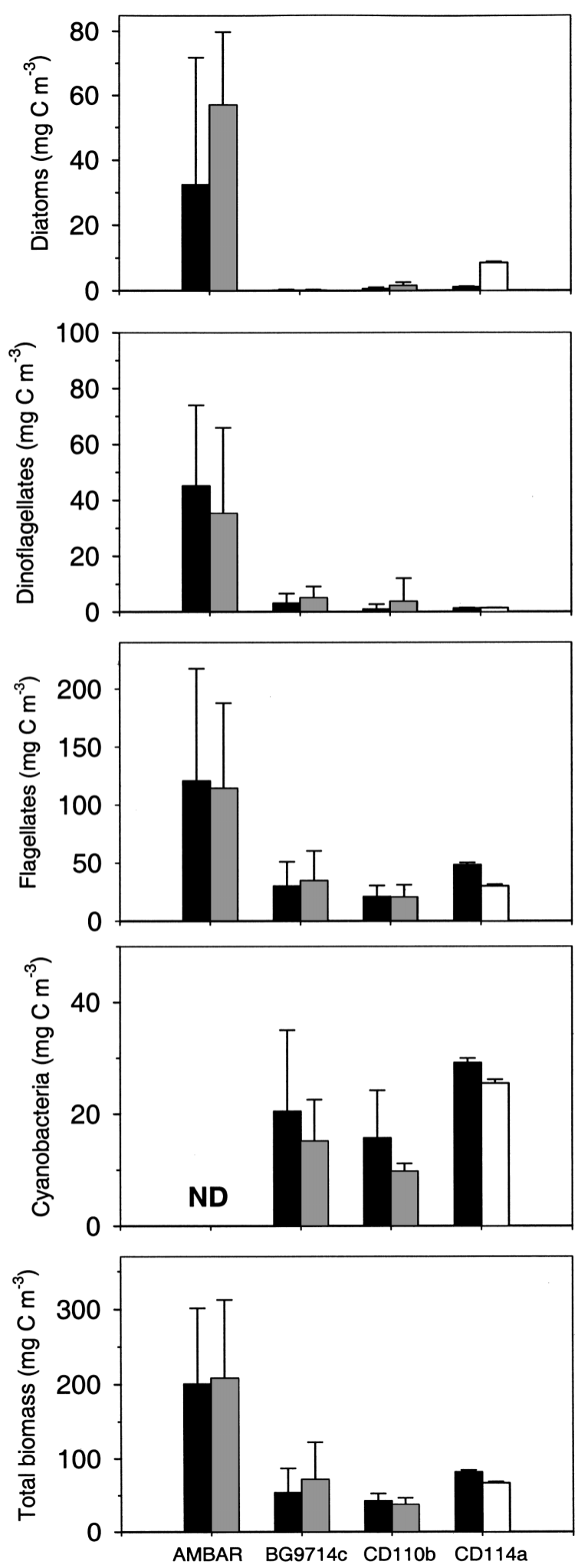

Fig. 7. Carbon biomass (mean $\pm \mathrm{SD}_{i} \mathrm{mg} \mathrm{C} \mathrm{m}^{-3}$ ) of diatoms, dinoflagellates, flagellates, cyanobacteria and total phytoplankton during the 4 cruises along the NW Iberian Peninsula. Black bars: shelf stations; grey bars: oceanic stations. For CD114a, black bars: upwelling; white bars: upwelling-relaxation 
Table 2. Light limited slope, $\alpha^{B}\left(\mathrm{mgC}[\mathrm{mg} \mathrm{chl} a]^{-1} \mathrm{~h}^{-1}\left[\mu \mathrm{mol} \mathrm{m} \mathrm{m}^{-2} \mathrm{~s}^{-1}\right]^{-1}\right)$, maximum photosynthetic rate, $P_{m}^{B}\left(\mathrm{mgC}[\mathrm{mg} \mathrm{chl} \mathrm{a}]^{-1} \mathrm{~h}^{-1}\right)$, light saturation parameters,

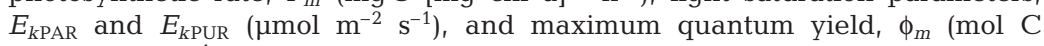
$[\mathrm{mol} \text { photons }]^{-1}$ ) during different hydrographic conditions along the NW Iberian Peninsula. Means \pm SE are shown

\begin{tabular}{|c|c|c|c|c|c|}
\hline & $\alpha^{B}$ & $P_{m}^{B}$ & $E_{k \mathrm{PAR}}$ & $\phi_{m}$ & $E_{k \text { PUR }}$ \\
\hline \multicolumn{6}{|c|}{ Spring downwelling (Cruise AMBAR, $n=34$ ) } \\
\hline Total & $0.023 \pm 0.001$ & $3.43 \pm 0.13$ & $160 \pm 3$ & $0.072 \pm 0.001$ & $2.05 \pm 0.05$ \\
\hline Shelf & $0.031 \pm 0.002$ & $4.47 \pm 0.36$ & $153 \pm 6$ & $0.075 \pm 0.002$ & $1.75 \pm 0.07$ \\
\hline Ocean & $0.016 \pm 0.0005$ & $2.40 \pm 0.09$ & $169 \pm 7$ & $0.069 \pm 0.002$ & $2.33 \pm 0.11$ \\
\hline \multicolumn{6}{|c|}{ Summer stratification (Cruise BG9714c, $n=40$ ) } \\
\hline Total & $0.033 \pm 0.001$ & $3.44 \pm 0.05$ & $148 \pm 3$ & $0.051 \pm 0.001$ & $0.87 \pm 0.098$ \\
\hline Shelf & $0.032 \pm 0.0006$ & $3.59 \pm 0.09$ & $145 \pm 5$ & $0.051 \pm 0.001$ & $0.92 \pm 0.03$ \\
\hline Ocean & $0.034 \pm 0.0015$ & $3.25 \pm 0.11$ & $151 \pm 7$ & $0.052 \pm 0.001$ & $0.81 \pm 0.03$ \\
\hline \multicolumn{6}{|c|}{ Winter poleward flow (Cruise CD110b, $\mathrm{n}=18$ ) } \\
\hline Total & $0.033 \pm 0.001$ & $1.51 \pm 0.02$ & $54 \pm 1$ & $0.087 \pm 0.002$ & $0.28 \pm 0.01$ \\
\hline Shelf & $0.030 \pm 0.002$ & $1.53 \pm 0.06$ & $63 \pm 3$ & $0.073 \pm 0.006$ & $0.27 \pm 0.01$ \\
\hline Ocean & $0.036 \pm 0.001$ & $1.47 \pm 0.04$ & $43 \pm 1$ & $0.104 \pm 0.001$ & $0.28 \pm 0.01$ \\
\hline \multicolumn{6}{|c|}{ Summer upwelling (Cruise CD114a, $n=40$ ) } \\
\hline Total & $0.068 \pm 0.004$ & $8.26 \pm 0.38$ & $135 \pm 62$ & $0.095 \pm 0.005$ & $2.84 \pm 0.33$ \\
\hline Upwell. & $0.083 \pm 0.003$ & $8.86 \pm 0.55$ & $108 \pm 8$ & $0.097 \pm 0.007$ & $2.96 \pm 0.51$ \\
\hline Relax. & $0.046 \pm 0.003$ & $7.40 \pm 0.44$ & $174 \pm 18$ & $0.091 \pm 0.007$ & $2.66 \pm 0.37$ \\
\hline
\end{tabular}
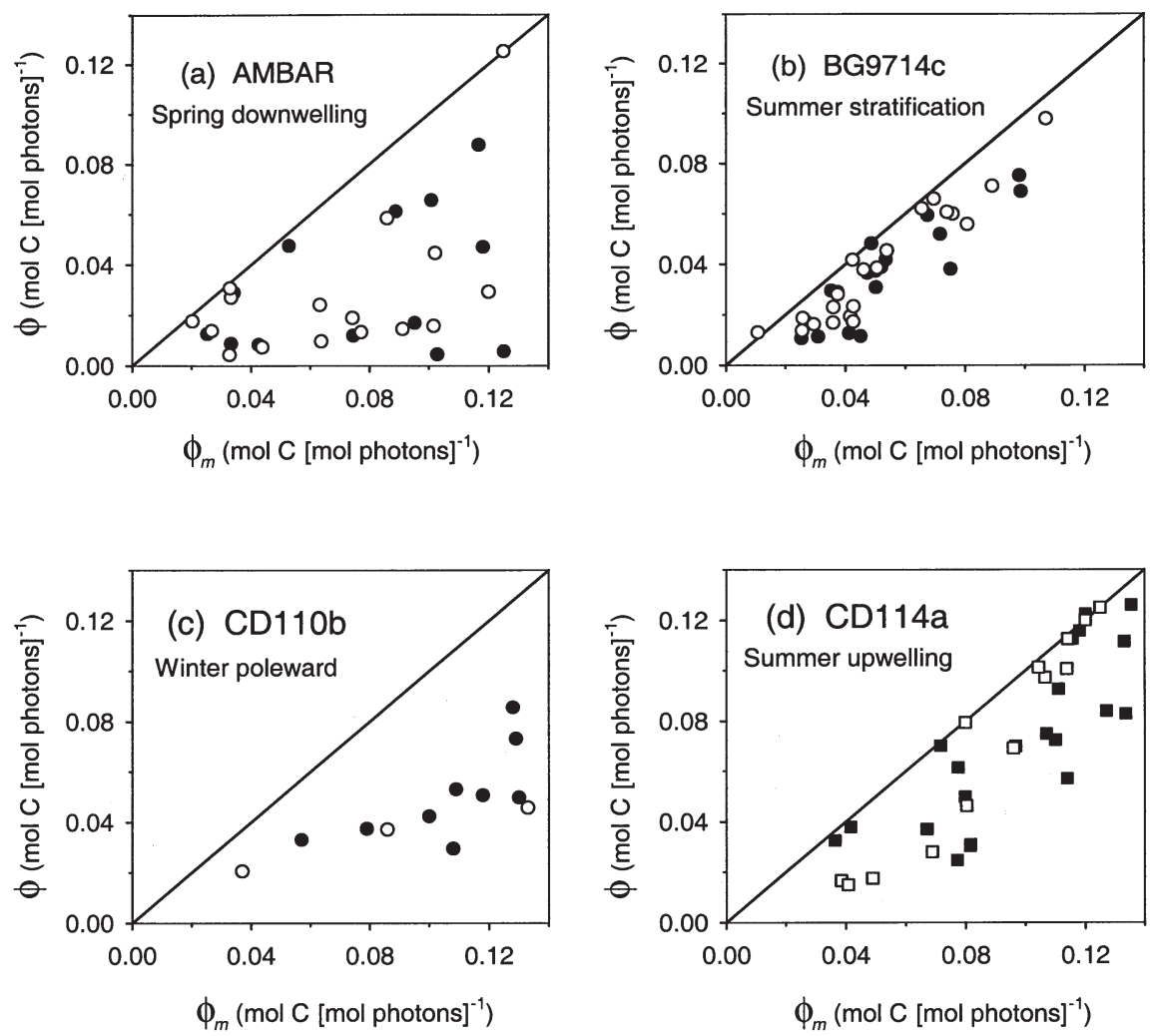

Fig. 8. Maximum quantum yield versus in situ quantum yield to $0.1 \%$ irradiance depth for (a) spring downwelling, (b) summer stratification, (c) winter poleward flow, (d) summer upwelling. Solid line represents 1:1 relationship. o shelf stations; $\bullet$ oceanic stations; - upwelling; $\square$ upwelling relaxation tation in $20 \%$ of the samples during spring downwelling (Fig. 8a) and a higher percentage of samples showed light limitation over the shelf $(25 \%)$ than in the open ocean $(15 \%)$. By comparison, during summer stratification only $14 \%$ of the samples were light-limited, and more frequently at shelf stations $(18 \%)$ than at oceanic stations (5\%; Fig. 8b); samples showed lower dispersion and values closer to the 1:1 line. During winter poleward flow (Fig. 8c) there was no evidence of light limitation even though the irradiance values were lowest. During upwelling, light limitation was greatest during wind relaxation (Fig. 8d) when the chl a maximum occurred deeper in the water column over the shelf (Fig. 6d) and $40 \%$ of the samples had light limitation (highest maximum quantum yield values in Fig. 8d).

\section{Integrated primary production}

PP was highest during summer upwelling for $\sum P P_{\mathrm{PAR}}\left(F_{3,49}=93.40, \mathrm{p}<\right.$ $0.001)$ and $\sum P P_{\mathrm{PUR}}\left(F_{3,49}=99.41, \mathrm{p}<\right.$ 0.001 ) (Table 3 ). For both $\sum P P_{\mathrm{PAR}}$ and $\sum P P_{\text {PUR }}$ the poleward current exhibited the lowest values (Table 3 ). There was little difference between shelf and ocean stations during spring downwelling and summer stratification but there were higher values at the shelf during winter poleward flow.

On average the $\sum P P_{\mathrm{PAR}}$ model gave values $21 \%$ lower than the spectral model $\sum P P_{\text {PUR }}$ (Fig. 9a). The difference was $24 \%$ during spring downwelling (Fig. 9b), 38\% during summer stratification $38 \%$ (Fig. 9c), $31 \%$ during winter poleward flow (excluding one outlier; diamond in Fig. 9d), and 17\% during summer upwelling (Fig. 9e).

\section{DISCUSSION}

\section{Dominance of small phytoplankton}

At the NW Iberian upwelling system diatoms dominate the phytoplankton 
Table 3. $\sum P P_{\mathrm{PAR}}$ and $\sum P P_{\mathrm{PUR}}\left(\mathrm{mgC} \mathrm{m} \mathrm{m}^{-2} \mathrm{~d}^{-1}\right.$; mean $\left.\pm \mathrm{SE}\right)$ during different hydrographic conditions along the NW Iberian Peninsula

\begin{tabular}{|c|c|c|}
\hline & $\sum P P_{\mathrm{PAR}}$ & $\sum P P_{\mathrm{PUR}}$ \\
\hline \multicolumn{3}{|c|}{ Spring downwelling (Cruise AMBAR, $n=18$ ) } \\
\hline Total & $1663 \pm 30$ & $2011 \pm 35$ \\
\hline Shelf & $1625 \pm 40$ & $1965 \pm 49$ \\
\hline Ocean & $1714 \pm 85$ & $2076 \pm 96$ \\
\hline \multicolumn{3}{|c|}{ Summer stratification (Cruise BG9714c, $n=10$ ) } \\
\hline Total & $453 \pm 60$ & $744 \pm 55$ \\
\hline Shelf & $425 \pm 72$ & $749 \pm 25$ \\
\hline Ocean & $482 \pm 49$ & $739 \pm 34$ \\
\hline \multicolumn{3}{|c|}{ Winter poleward flow (Cruise CD110b, $n=12$ ) } \\
\hline Total & $136 \pm 13$ & $214 \pm 22$ \\
\hline Shelf & $166 \pm 12$ & $286 \pm 13$ \\
\hline Ocean & $124 \pm 4$ & $184 \pm 6$ \\
\hline \multicolumn{3}{|c|}{ Summer upwelling (Cruise CD114a, $n=10$ ) } \\
\hline Total & $2151 \pm 165$ & $2595 \pm 213$ \\
\hline Upwelling & $2397 \pm 197$ & $2959 \pm 255$ \\
\hline Relaxation & $1783 \pm 227$ & $2105 \pm 239$ \\
\hline
\end{tabular}

biomass in the inshore waters of the Rías (e.g. Tilstone et al. 1999, 2000), in coastal shelf waters during upwelling episodes (Estrada 1984, Varela et al. 1991) and during the spring bloom (Fernández et al. 1991). Small phytoplankton forms were more abundant in nearshore open ocean waters. Fig. 7 shows that nano- (flagellates) and pico- (cyanobacteria) phytoplankton constitute the bulk of the phytoplankton biomass at shelf and open ocean locations. We expected diatoms to dominate during summer upwelling (Cruise CD114a), but found that pico- and nano-phytoplankton were more abundant. Diatom biomass was only important during spring, but it was always lower than the total flagellate biomass; a clear differentiation between autotrophic and heterotrophic flagellates was not possible during the spring (Cruise AMBAR). The dominance of small phytoplankton forms during periods when microphytoplankton dominance would have been expected (Estrada 1984, Varela et al. 1991, Bode et al. 1994) could be due to 2 factors: (1) during spring downwelling and winter poleward flow the open ocean is dominated by small phytoplankton (Alvarez-Salgado et al. 2002). Under the influence of southerly winds, offshore surface waters flow towards the coast and these small phytoplankton forms dominated at the narrow shelf margin (Fig. 1) and diatoms were confined to a narrow band off the coast (Castro et al. 1997) and Rias (Figueiras et al. 1987); (2) during summer upwelling, advected water from the Rias can have a high biomass of diatoms and a lower biomass of nano-phytoplankton (Tilstone et al. 1999). As the biomass is exported offshore, the diatoms are consumed or sedimented before they reach the shelf (Tilstone et al. 2000) while the nanophytoplankton remains suspended and accumulates over the shelf.

\section{Relationship between hydrography, phytoplankton biomass, photosynthetic parameters and primary production}

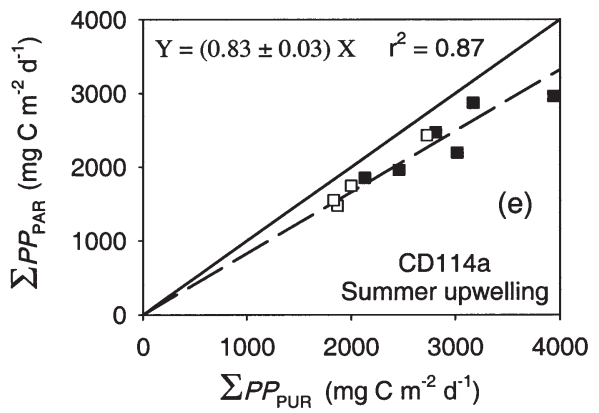

Fig. 9. Comparison of broad-band (PAR) and spectral (PUR) models of integrated PP during (a) all hydrographic conditions, (b) spring downwelling, (c) summer stratification, (d) winter poleward flow, (e) and summer upwelling conditions. Solid line represents 1:1 relationship. Dashed lines correspond to the regression (model II). - = shelf stations; $\mathrm{O}=$ oceanic stations. In (d) $\bullet$ excluded outlier. In (e) $\boldsymbol{\square}=$ upwelling; $\square=$ upwelling relaxation $\sum P P_{\text {PUR }}$ was significantly higher during summer upwelling, due to high $\phi_{m}$ and $P_{m}^{B}$ values in the surface layer where most of the production occurred, and PP was lower during winter poleward flow, due to low $P_{m}^{B}$ and low phytoplankton biomass. During Cruise AMBAR, although chl a levels were the highest of all cruises (Fig. 5a) as a result 
of the previous upwelling event (Figs 2 \& 3), PP was comparatively low (Table 3 ) due to low chlorophyllspecific maximum rates of carbon fixation, $P_{m}^{B}$.

The mean $P_{m}^{B}$ was 5.5 times higher during summer upwelling than during winter poleward flow (Table 2). $P_{m}^{B}$ is not dependent on light intensity and quality (Pickett \& Mayers 1966) and in the absence of nutrient limitation, the reactions that determine $P_{m}^{B}$ are enzymatically controlled and temperature dependent (Harris 1978). The broad-band light-limited slope $\alpha^{B}$ and the maximum quantum yield $\phi_{m}$ of the photosynthesisirradiance relationships are light dependent (Falkowski 1981). In the absence of significant changes in temperature, the adaptation of phytoplankton to different light regimes occurs through changes in $\alpha^{B}$ and $\phi_{m}$, and can be either due to physiological adaptation (Perry et al. 1981) or changes in species composition (Côté \& Gallegos 1983, Gallegos 1992). In this study, $P_{m}^{B}$ for each condition showed greater variation than $\alpha^{B}$ and $\phi_{m}$ values. During summer upwelling and winter poleward flow, the light regimes in the water column were extremely different; although surface temperatures and nutrient levels were similar (Table 1 \& Figs. 3 $\& 4 \mathrm{c}, \mathrm{d})$ there was considerable variation in $P_{m}^{B}$. By comparison, $\phi_{m}$ was significantly higher during summer upwelling, but this was only 2 times higher than the mean for summer stratification and 1.3 times higher than the mean for winter poleward flow. The data therefore suggest that adaptation to light regimes may also occur through changes in $P_{m}^{B}$. When daily mean values of $P_{m}^{B}$ were regressed against daily mean values of environmental variables and phytoplankton biomass, $89 \%$ of the variation in $P_{m}^{B}$ was explained by mean daily $E_{\mathrm{PUR}}$ and the biomass of flagellates and cyanobacteria (Table $4 \mathrm{a} \&$ Fig. 10); $62 \%$ of the variation in $P_{m}^{B}$ was explained by $E_{\mathrm{PUR}}$ alone (see also Fig. 10a). Morel (1991) and Antoine et al. (1996) observed that $P_{m}^{B}$ varies as a function of the temperature dependent variable $K_{\mathrm{PUR}}$, which also suggests a covariation between $P_{m}^{B}$ and spectral irradiance. Unexpectedly, we found no significant co-variation between $\phi_{m}$, and daily mean spectral irradiance, phytoplankton biomass and other environmental parameters such as nutrients. Similarly, Kyewalyanga et al. (1998) observed no significant co-variation between $\phi_{m}$ and environmental parameters in this region. Although $P_{m}^{B}$ and $\phi_{m}$ were significantly higher during Cruise CD114a, nutrient concentrations were not significantly different between conditions. The large variation in $P_{m}^{B}$ suggests that this is an important mechanism by which phytoplankton adapt to ambient environmental conditions. Furthermore, pooling all data from all cruises and employing forward stepwise multiple regression, we found that a high percentage of the variance in PP could be explained by alongshore Ekman transport, $Q_{\mathrm{y}}$
Table 4. Significant multiple stepwise regressions of (a) mean $P_{m}^{B}$ and (b) mean integrated primary production $\left(\mathrm{mg} \mathrm{C} \mathrm{m} \mathrm{m}^{-3}\right.$ $\mathrm{d}^{-1}$ ) against spectral irradiance absorbed by phytoplankton

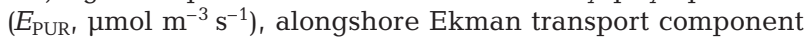
$\left(Q_{\mathrm{y}}, \mathrm{m}^{3} \mathrm{~s}^{-1} \mathrm{~km}^{-1}\right)$ and mean biomass of phytoplankton groups $\left(\mathrm{mgC} \mathrm{m}^{-3}\right) . P_{m}^{B}, \mathrm{PP}, E_{\mathrm{PUR}}$ and phytoplankton biomass are the average of the stations sampled each day. p: level of significance of the total regression, intercepts and slopes. ns: not significant. n: number of samples

(a) $\boldsymbol{P}_{m}^{B}$ (all cruises; $\mathrm{n}=25$ )

$\begin{array}{lrl}\mathrm{r}^{2}=0.89 & F_{3,11}=15.1 & \mathrm{p}<0.001 \\ & & \mathrm{p}=0.016 \\ \text { Intercept } & -2.07 \pm 0.73 & \mathrm{p}<0.001 \\ E_{\text {PUR }} & 2.20 \pm 0.27 & \mathrm{p}=0.01 \\ \text { Flagellates } & 0.05 \pm 0.02 & \mathrm{p}=0.04 \\ \text { Cyanobacteria } & 0.08 \pm 0.04 & \end{array}$

(b) $\sum \boldsymbol{P P}$ (all cruises; $\mathrm{n}=25$ )

\begin{tabular}{lcl}
$\mathrm{r}^{2}=0.57$ & $F_{2,23}=15.1$ & $\mathrm{p}<0.001$ \\
& $18.96 \pm 2.66$ & $\mathrm{p}<0.001$ \\
Intercept & $0.01 \pm 0.002$ & $\mathrm{p}<0.001$ \\
$Q_{\mathrm{y}}$ & $0.29 \pm 0.12$ & $\mathrm{p}=0.02$ \\
Diatoms & \\
\multicolumn{2}{c}{ (AMBAR excluded; $\mathrm{n}=18$ ) } \\
$\mathrm{r}^{2}=0.75$ & $F_{2,15}=22.5$ & $\mathrm{p}<0.001$ \\
Intercept & $2.44 \pm 5.9$ & $\mathrm{~ns}$ \\
$Q_{\mathrm{y}}$ & $0.008 \pm 0.002$ & $\mathrm{p}=0.001$ \\
Cyanobacteria & $0.92 \pm 0.28$ & $\mathrm{p}=0.005$
\end{tabular}

and the biomass of diatoms $\left(\mathrm{r}^{2}=0.57\right.$; Table $\left.4 \mathrm{~b}\right) . Q_{\mathrm{y}}$ alone explained $45 \%$ of the total variance in integrated PP. However, the intercept of the regression (18.96 \pm $2.66 \mathrm{mgC} \mathrm{m}^{-2} \mathrm{~d}^{-1}$ ) was higher than zero, indicating that a significant fraction of the PP cannot be explained by this relationship alone. Not all phytoplankton groups were determined during Cruise AMBAR, and pico- and nanophytoplankton could account for the unexplained fraction. When we omitted the AMBAR data, $75 \%$ of the variance in PP was explained by $Q_{\mathrm{Y}}$ and cyanobacteria biomass (Table $4 \mathrm{~b}$ ), the intercept was not significantly different from zero, and $Q_{\mathrm{Y}}$ explained $56 \%$ of the total variance. This contrasts with previous research, which in the absence of epifluorescence counts, suggested that the variation in diatom biomass alone caused the variation in PP along the NW Iberian Peninsula (Bode et al. 1994).

We then repeated the regression for shelf and ocean locations (data not shown). $Q_{\mathrm{y}}$ explained $52 \%$ of the variance in PP over the shelf, which was coupled with variations in $P_{m}^{B}$ (Fig. 10a) and the biomass of diatoms and flagellates. At oceanic locations, PP was coupled with variations in $P_{m}^{B}$ and the biomass of cyanobacteria (Fig. 10b), but only $7 \%$ of the variance in PP could be explained by $Q_{\mathrm{y}}$, indicating a decoupling between $Q_{\mathrm{Y}}$ 

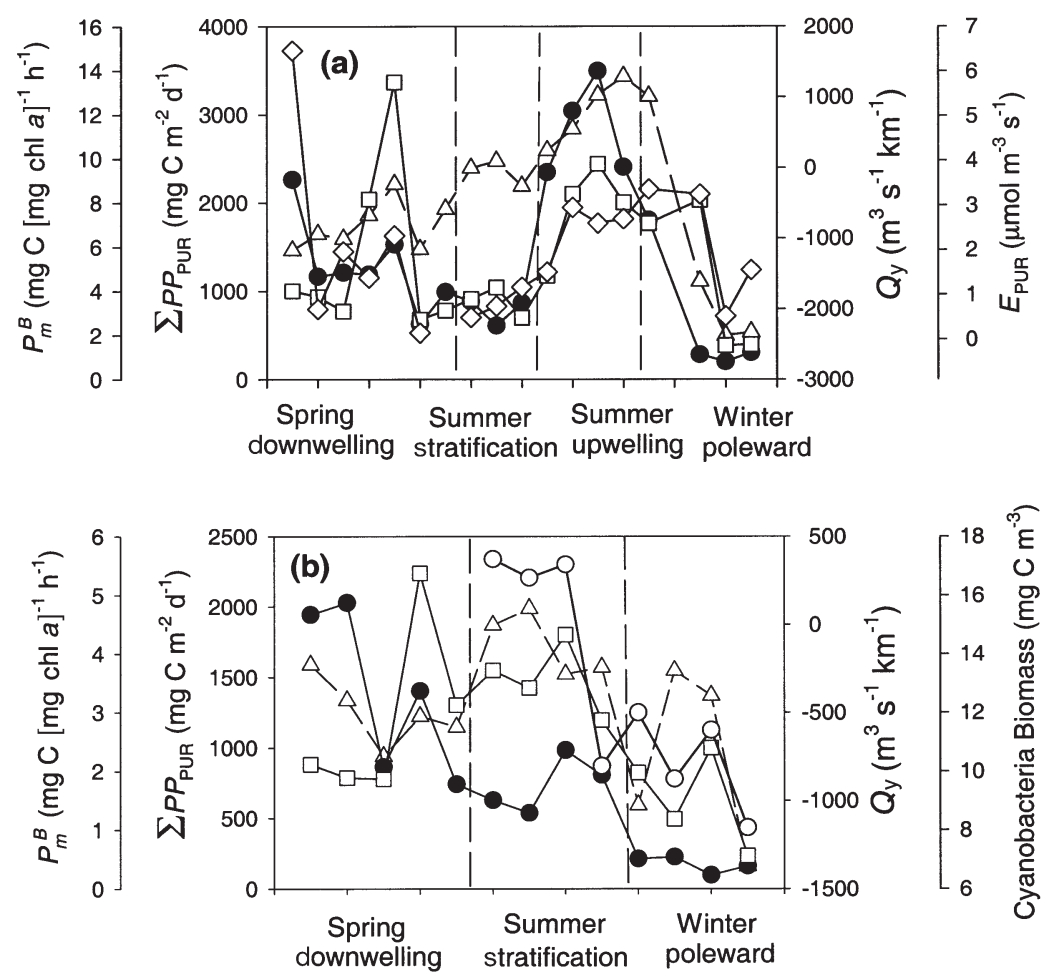

Fig. 10. Variations in some parameters over the shelf (a) and ocean (b) during different hydrographic conditions along the NW Iberian Peninsula: Ekman transport component parallel to the coast, $Q_{\mathrm{y}}(\Delta)$, primary production, $\sum P P_{\text {PUR }}$ $(\bullet)$, maximum photosynthetic rate, $P_{m}^{B}(\square)$, spectral irradiance $(\diamond$ in a), cyanobacteria biomass $(\mathrm{O}$ in $\mathrm{b})$

and integrated PP. We expected the correlation between $Q_{\mathrm{x}}$ and PP to be high, but it only explained $17 \%$ of the variation in PP over the shelf and $6 \%$ of the variation offshore. $Q_{\mathrm{y}}$ explained a consistently higher percentage of the variance, possibly because $Q_{\mathrm{y}}$ acts on a shorter time scale than $Q_{\mathrm{X}}$.

\section{Broad-band and spectral models of primary produc- tion, light limitation and hydrography}

Spectrally dependent models of computing PP have been reported to be up to $50 \%$ higher than those derived from broad-band parameters (Kyewalyanga et al. 1992). Figueiras et al. (1999) estimated PP using a phytoplankton light absorption model with the maximum quantum yield of photosynthesis derived from photosynthetic versus photosynthetic useable radiation curves. They found that models based on broad-band photosynthetic parameters and irradiance derived from the average attenuation coefficient underestimated PP by as much as $24 \%$, and that broad-band models conceal information on light limitation in phytoplankton. We found significant differences $(0.02>p>0.001)$ between light limitation depths of photosynthesis for the broad-band and spectral models during the 4 cruises (AMBAR, $16 \mathrm{~m}$ and $22 \mathrm{~m}$; BG9714c, 18m and 44m; CD110b, 14m and $18 \mathrm{~m} ; \mathrm{CD} 114 \mathrm{a}, 13 \mathrm{~m}$ and $16 \mathrm{~m}$, respectively). The broad-band approach significantly underestimated PP during spring downwelling and summer stratification, because light limitation occurred at shallower depths in the photic layer than for the spectral model. The results suggest that under the influence of southerly winds, during downwelling and poleward flow conditions, and when the water column is highly stratified, it is more accurate to use a spectral model of PP, because it provides a better simulation of light harvesting by phytoplankton during low irradiance close to light limitation. The broad-band model of $\sum P P_{\text {PAR }}$ could only be used with comparative accuracy during upwelling, when most of the biomass is in the surface layer at saturating irradiance.

\section{Sensitivity analysis}

We performed a sensitivity analysis to assess the variables that have the greatest influence on the computation of $\sum P P_{\text {PUR }}$. Variation in $\sum P P$ is due to first order variables such as photosynthetic pigment concentration and irradiance (Platt et al. 1991, Sathyendranath et al. 1995). More recently an increasing importance has been placed on $P_{m}^{B}$ to explain the variation in PP on basin and global scales (Balch et al. 1992, Marañon \& Holligan 1999). Behrenfeld \& Falkowski (1997), however, showed that the most important variable in the calculation of PP for a range of different models is chl a.

For different hydrographic scenarios at the NW Iberian upwelling margin, mean profiles of $\mathrm{chl} a, P_{m}^{B}$, $\phi_{m}$ and $E_{\text {PUR }}$ were fitted to mathematical functions. The form of each profile was calculated by normalising to its sum and using the range in real data for a particular hydrographic condition; 14 vertical profiles were reconstructed using the maths function form. $\sum P P_{\text {PUR }}$ was then computed for each hydrographic situation and location using the normalised mean value for each variable and and then re-computed by varying each variable sequentially through the 14 reconstructed data profiles.

Under homogeneous environmental conditions such as poleward flow (Fig. 11c), the spread of the 90th and 10th percentiles indicats that the variation in the parameters used to calculate $\sum P P$ is of lesser impor- 

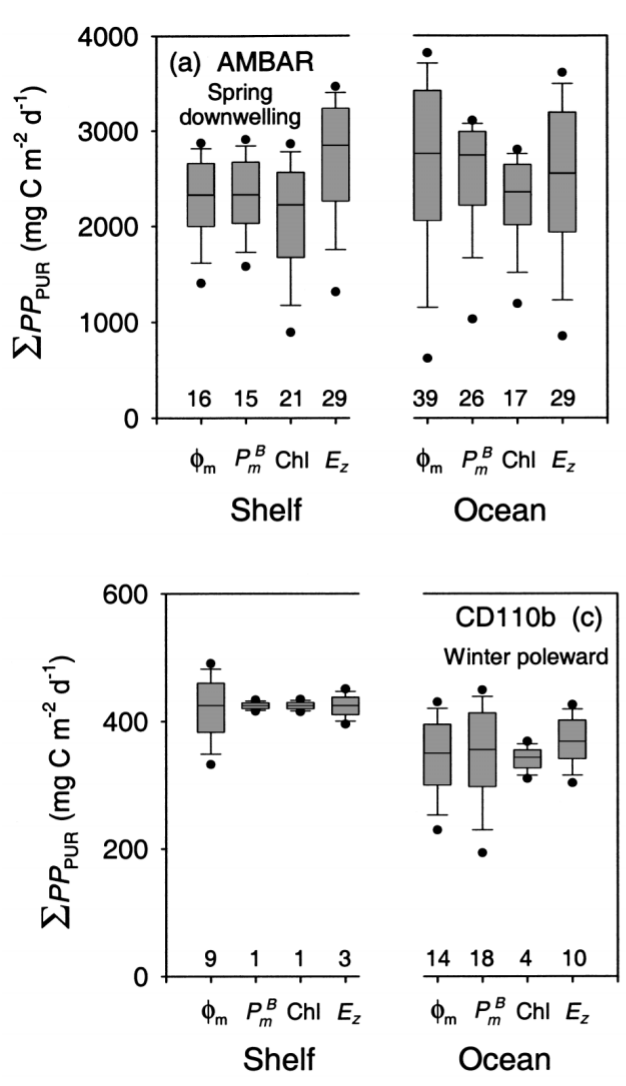
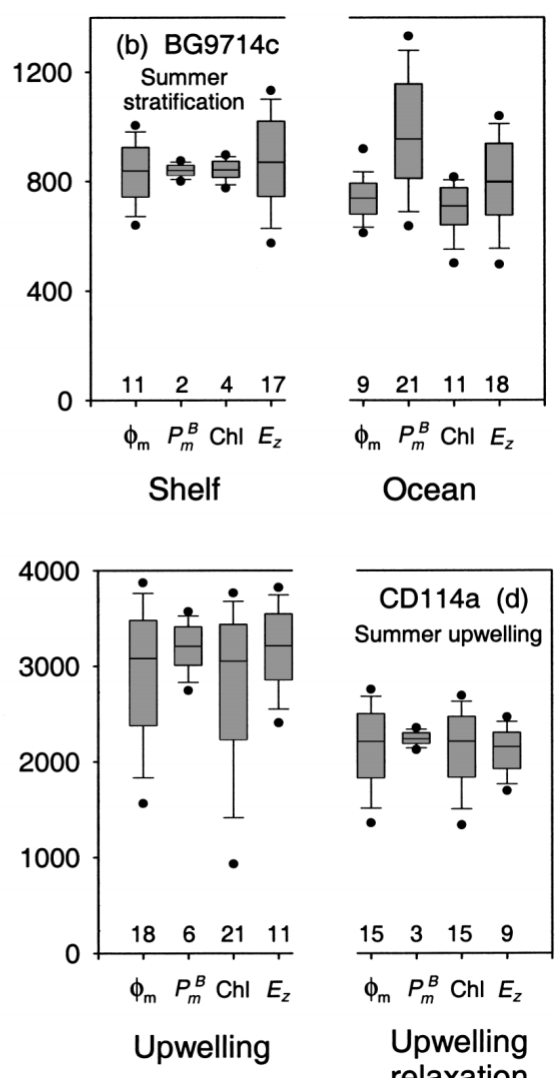

Fig. 11. Errors incurred in the calculation of $\sum P P_{\text {PUR }}$ for $\phi_{m}, P_{m}^{B}$, chl $a$ and $E_{z \text { PUR }}$ during (a) spring downwelling, (b) summer stratification, (c) winter poleward flow, (d) upwelling and wind relaxation. The boundary of the box indicates the 25th and 75th percentiles, the line within the box indicates the median, the whiskers above and below the box indicate the 90th and 10th percentiles, and the dots outside the box are outliers. The numbers given at the bottom of the plots are the mean errors incurred in calculating $\sum P P_{\mathrm{PUR}}$ by varying each parameter through its range for each hydrographic scenario tance compared to transitional hydrographic states (Figs. 11a,b). During transitional conditions (e.g. stratification), the 90th and 10th percentiles indicated that all variables affect the calculation of $\sum P P$ and it is therefore important to characterise in detail the vertical structure of the parameters used to derive $\Sigma P P$. The sensitivity analysis shows that $\phi_{m}$ and $E_{z P U R}$ were more important at coastal stations during downwelling, summer stratification and winter poleward flow (Figs. 11a,b,c) and that $P_{m}^{B}$ influenced the calculation of PP more at oceanic stations during summer stratification and winter poleward flow. These results suggest that wavelength dependent satellite algorithms of PP (e.g. Morel 1991), which incorporate the spectral light field and $\phi_{m}$ may be more appropriate for the NW Iberian Peninsula when there is low light adaptation or light limitation as observed during water column stratification, downwelling and poleward flow conditions. During upwelling when phytoplankton were transported to light saturated conditions and most of the biomass was concentrated in the top 5 to $15 \mathrm{~m}$ of the water column, chl a was the variable that caused the greatest variation in $\sum P P_{\text {PUR }}$ (Fig. 11d). Simple empirical satellite algorithms based on phytoplankton biomass (e.g. Eppley et al. 1985) may therefore be used with accuracy to compute $\Sigma P P$ in this region during upwelling, when most of the chl $a$ is at the surface and phytoplankton is at light saturation.

\section{Conclusions}

The maximum photosynthetic rate, $P_{m}^{B}$, co-varied with spectral irradiance and with the biomass of flagellates and cyanobacteria along the NW Iberian upwelling margin. Over the shelf $P_{m}^{B}$ was tightly coupled to $E_{\text {PUR }}$ and to the biomass of flagellates and diatoms, whereas at oceanic stations $P_{m}^{B}$ was coupled with the biomass of cyanobacteria only. Pooling shelf and oceanic data, $75 \%$ of the variance in PP was explained by $Q_{\mathrm{y}}$ and by the biomass of cyanobacteria and diatoms. This contrasts with the dynamics of the Rías, where diatoms account for most of the fixed carbon and the crossshore component of Ekman transport, $Q_{\mathrm{X}}$, explains a higher percentage of the variation in PP.

Integrated PP was significantly higher during upwelling compared with all other hydrographic conditions. The difference between broad-band, $\sum P P_{\mathrm{PAR}}$ and spectral $\sum P P_{\text {PUR }}$ models of $P P$ was low during upwelling, but significantly higher during downwelling, poleward and stratified conditions, due to sig- 
nificant differences in light limitation depths, as indicated by $E_{\text {kPAR }}$ and $E_{\mathrm{kPUR}}$. A sensitivity analysis showed that integrated PP was more influenced by spectral irradiance and photosynthetic parameters when southerly winds prevailed and during stratified conditions; this suggests that wavelength dependent satellite algorithms may give more accurate estimates of PP under these conditions. Under the influence of northerly winds during upwelling, chl a was the single most important variable in the calculation of integrated $\mathrm{PP}$; this suggests that empirical satellite algorithms based on $\log \mathrm{chl} a$ are appropriate for the computation of PP along the NW Iberian Peninsula.

Acknowledgements. We thank S. B. Groom of Plymouth Marine Laboratory for AVHRR SST satellite images. We are grateful to the captain and crew of RV 'Charles Darwin', RV 'Belgica', and RV 'Cornide de Saavedra' and principal scientists Drs. I. R. Joint, A. E. J Miller, L. Chou and A. Bode. Microplankton counts from AMBAR were provided by Dr. M. Varela of Instituto Español de Oceanografía. We thank Drs. X.A. Alvarez-Salgado, N. Brion, L. Chou, M. Elskens and A. Varela for nutrient data. The AMBAR cruise was conducted with funding of the Spanish project CICYT-AMB930129. The other cruises were conducted in the framework of the EU MAST programme OMEX II-Phase II and the Spanish project MAR97-2068-CE. B.A. was funded by a post graduate grant from the CSIC-Xunta de Galicia. L.M.L was supported by a studentship from the Spanish Ministerio de Educación y Ciencia and G.H.T by a fellowship from the European Commission MAST programme (MAS3-CT96-5022).

\section{LITERATURE CITED}

Alvarez-Salgado XA, Figueiras FG, Pérez FF, Groom S and 10 others (2003) The Portugal coastal counter current off NW Spain: new insight on its biogeochemical variability. Progr Oceanogr 56(2):281-321

Alvarez-Salgado XA, Rosón G, Pérez FF, Figueiras FG, Pazos Y (1993) Hydrographic variability off the Rías Biaxas (NW Spain) during the upwelling season. J Geophys Res 98: 14447-14455

Arbones B, Figueiras FG, Varela R (2000) Action spectrum and maximum quantum yield of carbon fixation in natural phytoplankton populations: implications for primary production estimates in the ocean. J Mar Systems 26:97-114

Arbones B, Figueiras FG, Zapata M (1996) Determination of phytoplankton absorption coefficients in natural sea water samples: evidence of a unique equation to correct for pathlength amplification on glass fibre filters. Mar Ecol Prog Ser 137:293-304

Balch W, Evans R, Brown J, Feldman G, McClain C, Esaias W (1992) The remote sensing of ocean productivity: Use of a new data compilation to test satellite algorithms. J Geophys Res 97:2279-2293

Bannister TT, Weidemann AD (1984) The maximum quantum yield of phytoplankton photosynthesis. J Plankton Res 6: 275-294

Behrenfeld MJ, Falkowski PG (1997) A consumers guide to phytoplankton primary productivity models. Limnol Oceanogr 42:1479-1491

Blanton JO, Atkinson LP, Castillejo FF, Montero AL (1984)
Coastal upwelling off the Rias Bajas, Galicia, North West Spain. I. Hydrographic studies. Rapp PV Réun Cons Int Explor Mer 183:79-90

Blanton JO, Tenore KR, Castillejo FF, Atkinson LP, Scgwing FB, Lavín A (1987) The relationship of upwelling to mussel production in the rías on the western coast of Spain. J Mar Res 45:497-511

Bode A, Fernandez E (1992) Influence of water-column stability on phytoplankton size and biomass succession patterns in the central Cantabrian Sea (Bay of Biscay). J Plankton Res 14:885-902

Bode A, Casas B, Varela M (1994) Size-fractionated primary productivity and biomass in the Galician shelf (NW Spain): netplankton versus nanoplankton dominance. Sci Mar 58: 131-141

Bode A, Fernandez E, Botas A, Anadon R (1990) Distribution and composition of suspended particulate matter related to a shelf-break saline intrusion in the Cantabrian Sea (Bay of Biscay). Oceanol Acta 13:219-228

Both BC (1988) Size class and major taxonomic groups of phytoplankton at two locations in the Subartic Pacific Ocean in May and August, 1984. Mar Biol 97:275-286

Bricaud A, Stramski D (1990) Spectral absorption coefficients of living phytoplankton and nonalgal biogenous matter: a comparison between the Peru upwelling area and the Sargasso Sea. Limnol Oceanog 35:562-582

Castro CG, Alvarez-Salgado XA, Figueiras FG, Pérez FF, Fraga F (1997) Transient hydrographic and chemical conditions affecting microplankton populations in the coastal transition zone of the Iberian upwelling system (NW Spain) in September 1986. J Mar Res 55:321-352

Castro CG, Pérez FF, Alvarez-Salgado XA, Rosón G, Ríos AF (1994) Hydrographic conditions associated with the relaxation of an upwelling event off the Galician coast (NW Spain). J Geophys Res 99:5135-5147

Côté B, Platt T (1984) Utility of the light-saturation curve as an operational model for quantifying the effects of environmental conditions on phytoplankton photosynthesis. Mar Ecol Prog Ser 18:57-66

Dubinsky Z (1980) Light utilization efficiency in natural phytoplankton communities. In: Falkowski PG (ed) Primary productivity in the sea. Plenum Press, New York, p 83-97

Edler L (1979) Recommendations for marine biological studies in the Baltic Sea: phytoplankton and chlorophyll. Baltic Mar Biol 5:38

Eppley RW, Stewart E, Abbott MR, Heyman U (1985) Estimating ocean primary production from satellite chlorophyll: introduction to regional differences and statistics for the Southern California Bight. J Plankton Res 7:57-7

Estrada M (1984) Phytoplankton distribution and composition off the coast of Galicia (North West Spain). J Plankton Res $6: 417-434$

Falkowski PG (1981) Light-shade adaptation and assimilation numbers. J Plankton Res 3:203-216

Fernandez E, Bode A, Botas A, Anadon R (1991) Microplankton assemblages associated with saline fronts during a spring bloom in the central Cantabrian Sea: differences in trophic structure between water bodies. J Plankton Res 13: 1239-1256

Figueiras FG, Arbones B, Estrada M (1999) Implications of bio-optical modeling of phytoplankton photosynthesis in Antarctic waters: further evidence of no light limitation in the Bransfield Strait. Limnol Oceanogr 44:1599-1608

Figueiras FG, Niell FX (1987) Composición del fitoplancton en la Ría de Pontevedra (NO de España). Inv Pesq 51:371-409 Fraga F (1981) Upwelling off the Galician coast, northwest 
Spain. In: Richards FA (ed) Coastal upwelling. American Geophysical Union, Washington, DC, p 176-182

Frouin R, Fiúza AFG, Ambar I, Boyd TJ (1990) Observations of a poleward surface current off the coasts of Portugal and Spain during winter. J Geophys Res 95:679-691

Gallegos CL (1992) Phytoplankton photosynthesis, productivity and species composition in a eutrophic estuary: comparison of bloom and non-bloom assemblages. Mar Ecol Prog Ser 81:257-267

Gregg WW, Carder KL (1990) A simple spectral solar irradiance model for cloudless maritime atmospheres. Limnol Oceanogr 35:1657-1675

Harris GP (1978) Photosynthesis, productivity and growth: the physiological ecology of phytoplankton. Arch Hydrobiol Beih Ergebn Limnol 10:1-71

Hidy GM (1972) A review of recent air-sea interaction research. Bull Am Meteorol Soc 53:1083-1102

Kiefer DA, Soohoo JB (1982) Spectral absorption by marine particles of coastal waters off Baja California. Limnol Oceannogr 27:492-499

Kishino M, Okami N, Takahashi M, Ichimura S (1985) Estimation of the spectral absorption coefficients of phytoplankton in the sea. Bull Mar Sci 37:634-642

Kyewalyanga MN, Platt T, Sathyendranath S (1992) Ocean primary production calculated by spectral and broad-band models. Mar Ecol Prog Ser 85:171-185

Kyewalyanga MN, Platt T, Sathyendranath S (1997) Estimation of the photosynthetic action spectrum: implication for primary production models. Mar Ecol Prog Ser 146:207-223

Kyewalyanga MN, Platt T, Sathyendranath S, Lutz VA, Stuart V (1998) Seasonal variations in physiological parameters of phytoplankton across the North Atlantic. J Plankton Res 20:17-42

Lavín A, Díaz del Río G, Cabanas JM, Casas G (1991) Afloramiento en el noroeste de la Península Ibérica. Indices de afloramiento para el punto $43^{\circ} \mathrm{N}, 11^{\circ} \mathrm{W}$ : período $1966-$ 1989. Inf Tec Inst Esp Oceanogr 91:1-40

Laws EA, Redalje LW, Haas LW, Bienfang PK, Eppley RW, Harrison WG, Karl DM, Marra J (1984) High phytoplankton growth and production rates in oligotrophic Hawaiian coastal waters. Limnol Oceanogr 29:1161-1169

Lessard EF, Swift E (1986) Dinoflagellates from the North Atlantic classified as phototrophic or heterotrophic by epifluorescence microscopy. J Plankton Res 8:1209-1215

Mann KH (1993) Physical oceanography, food chains, and fish stocks: a review. ICES J Mar Sci 50:105-119

Marañon E, Holligan PM (1999) Photosynthetic parameters of phytoplankton from $50^{\circ} \mathrm{N}$ to $50^{\circ} \mathrm{S}$ in the Atlantic Ocean. Mar Ecol Prog Ser 176:191-203

McClain CR, Chao SY, Atkinson LP, Blanton JO, Castillejo F (1986) Wind-driven upwelling in the vicinity of Cape Finisterre, Spain. J Geophys Res 91:8470-8486

Mitchell DA, Holm-Hansen O (1991) Observations and modeling of the Antartic phytoplankton crop in relation to mixing depth. Deep-Sea Res II 38:981-1007

Morel A (1991) Light and marine photosynthesis: A spectral model with geochemical and climatological implications. Prog Oceanogr 26:263-306

Morel A, Antoine D, Babin M, Dandonneau Y (1996) Measures and modelled primary production in the northeast Atlantic (EUMELI JGOFS program): the impact of natural

Editorial responsibility: Otto Kinne (Editor), Oldendorf/Luhe, Germany variations in photosynthetic parameters on model predictive skill. Deep-Sea Res I 43:1273-1304

Pérez FF, Alvarez-Salgado XA, Rosón G (2000) Stoichiometry of the net ecosystem metabolism in a coastal inlet affected by upwelling: the Ría de Arousa (NW Spain). Mar Chem 69:217-236

Perry MJ, Talbot MC, Alberte RS (1981) Photoadaptation in marine phytoplankton: response of the photosynthetic unit. Mar Biol 62:91-101

Pickett JM, Myers J (1966) Monochromatic light saturation curves for photosynthesis in Chlorella. Plant Physiol 41: 90-98

Platt T, Caverhill C, Sathyendranath S (1991) Basin-scale estimates of oceanic primary production by remote sensing: the north Atlantic. J Geophys Res 96:15147-15159

Platt T, Gallegos CL, Harrison WG (1980) Photoinhibition of photosynthesis in natural assemblages of marine phytoplankton. J Mar Res 38:687-701

Rosón G, Alvarez-Salgado XA, Pérez FF (1997) A nonstationary box-model to determine residual flows in a partially mixed estuary, based on both thermohaline properties: application to the Ría de Arousa (NW Spain). Estuar Coast Shelf Sci 44:249-262

Sathyendranath S, Longhurst A, Caverhill CM, Platt T (1995) Regionally and seasonally differentiated primary production in the North Atlantic. Deep-Sea Res I 42: 1773-1802

Smith EL (1936) Photosynthesis in realtion to light and carbon dioxide. Proc Natl Acad Sci USA 22:504-511

Smith WO, Heburn GW, Barber RT, O'Brien JJ (1983) Regulation of phytoplankton communities by physical processes in upwelling systems. J Mar Res 41:539-556

Strathmann R (1967) Estimating the organic carbon content of phytoplankton from cell volume or plasma volume. Limnol Oceanogr 12:411-418

Tilstone GH, Figueiras FG, Fermín EG, Arbones B (1999) The significance of nano-phytoplankton photosynthesis and primary productivity in a coastal upwelling ecosystem (Ría de Vigo, NW Spain). Mar Ecol Prog Ser 183:13-27

Tilstone GH, Miguez BM, Figueiras FG, Fermín EG (2000) Diatom dynamics in a coastal ecosystem affected by upwelling: coupling between species succession, circulation and biogeochemical processes. Mar Ecol Prog Ser 205: $23-41$

Utermöhl H (1958) Zur Vervollkommnung der quantitativen Phytoplankton-Methodik. Mitt Int Verein Theor Angew Limnol 9:1-38

Varela M, Díaz del Río G, Alvarez-Osorio MT, Costas E (1991) Factors controlling phytoplankton size class distribution in the upwelling area of the Galician continental shelf (NW Spain). Sci Mar 55:505-518

Verity PG, Roberton CY, Tronzo CR, Andrews MG, Nelson JR, Sieracki ME (1992) Relationships between cell volume and the carbon and nitrogen content of marine photosynthetic nanoplankton. Limnol Oceanogr 48:357-366

Wooster WS, Bakun A, McClain DR (1976) The seasonal upwelling cycle along the eastern boundary of the North Atlantic. J Mar Res 34:131-141

Yentsch CS, Menzel DW (1963) A method for the determination of phytoplankton chlorophyll and phaeophytin by fluorescence. Deep-Sea Res I 10:221-231

Submitted: January 14, 2002; Accepted: November 27, 2002 Proofs received from author(s): April 7, 2003 